UNIVERSITY OF CALIFORNIA COLLEGE OF AGRICULTURE AGRICULTURAL EXPERIMENT STATION BERKELEY, CALIFORNIA

\title{
EFFECT OF PARTIAL CUTTING IN THE VIRGIN STAND UPON THE GROWTH AND TAPER OF WESTERN YELLOW PINE
}

FRANCIS X. SCHUMACHER

BULLETIN 540

SEPTEMBER, 1932 


\section{CONTENTS}

PAGE

Introduction...

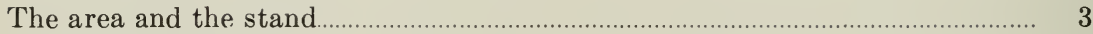

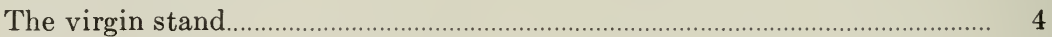

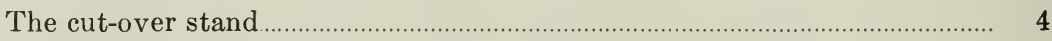

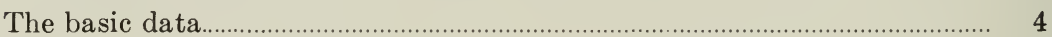

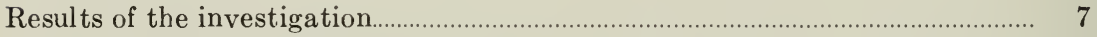

Comparison by volume board measure .......................................................... 7

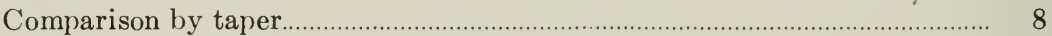

Comparison by diameter growth along the stems........................................ 11

Detailed analysis of the data............................................................................. 13

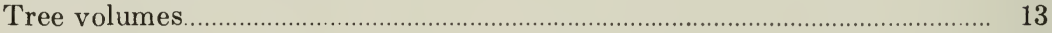

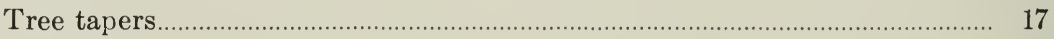

The 1928 taper of the trees from the virgin stand.................................. 18

Comparison of the tree tapers from the virgin and cut-over stands in 1909 and 1928

The taper by tree class.............................................................................. 24

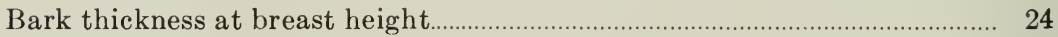

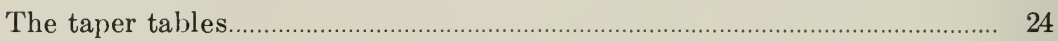

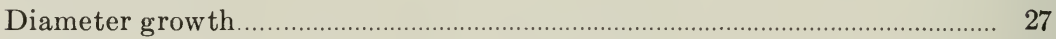

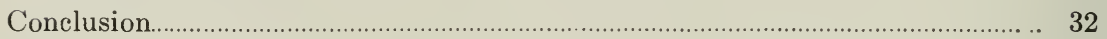


Note: The Western Pine Association and the United States Forest Service have now adopted the name PONDEROSA PINE instead of western yellow pine. 
Digitized by the Internet Archive in 2012 with funding from University of California, Davis Libraries 


\title{
EFFECT OF PARTIAL CUTTING IN THE VIRGIN STAND UPON THE GROWTH AND TAPER OF WESTERN YELLOW PINE ${ }^{1}$
}

\author{
FRANCIS X. SCHUMACHER 2, 3
}

\section{INTRODUCTION}

In the early summer of 1910, a moderately heavy selective cutting was made on the government timber-sale area in the Stanislaus National Forest. During the summer of 1928 a second cutting was made on this same previously cut-over area, as well as a first cutting in the adjoining virgin timber.

This afforded an opportunity to investigate (1) the form or taper of virgin timber by the method of stem analysis, and (2) changes in form and growth following the opening up of the virgin stand 18 years previously. This paper aims to set forth the results of the study for western yellow pine (Pinus ponderosa), the only species in sufficient numbers for reliable basic data.

\section{THE AREA AND THE STAND}

The area is on the watershed of the North Fork of the Tuolumne River in sections 29 and 32, township 4 north, range 18 east, Mt. Diablo meridian, at an average elevation of about 5,800 feet. The soil is fine, sandy loam of granitic origin. Normal precipitation is probably about 45 inches, though no records of much value have been kept nearby. The general aspect of the logged-off area is north-easterly with gentle to moderately steep slopes.

The timber vegetation is of the western-yellow-pine-sugar-pine type with white fir and incense cedar. As the tallest trees were well over 200 feet high, the area is classed as Site Quality I.

For convenience, the stand first cut in 1910 and later in 1928 will be designated as the cut-over stand, and the stand first cut in 1928 as the virgin stand.

1 Received for publication May 27, 1932.

2 Assistant Professor of Forestry and Assistant Forester in the Experiment Station; resigned November 16, 1930.

3 The writer is indebted to Director E. I. Kotok of the California Forest Experiment Station, United States Department of Agriculture, for information which led to the gathering of data for this investigation; and to Mr. Duncan Dunning for personal instruction of the field assistants in the identification of tree classes. 


\section{THE VIRGIN STAND}

This was in the south half of section 29 and the northeast quarter of section 32. From the cruise of these three quarter-sections made by the United States Forest Service in 1926, the stand per acre averaged 59,000 feet board measure distributed among the species shown in table 1.

TABLE 1

Virgin Stand by Species

\begin{tabular}{|c|c|}
\hline Species & $\begin{array}{c}\text { Board measure, } \\
\text { in per cent } \\
\text { by volume }\end{array}$ \\
\hline Western yellow pine................. & 22 \\
\hline 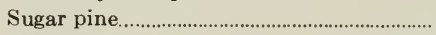 & 53 \\
\hline 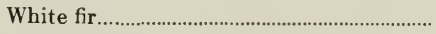 & 20 \\
\hline 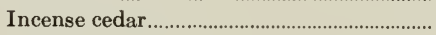 & 5 \\
\hline
\end{tabular}

\section{THE CUT-OVER STAND}

This was in the northwest quarter of section 32. Its original volume is not known, but as the 1928 cutting was taken mostly from a Forest Service 20-acre permanent sample plot, established in the summer of 1910, a fair estimate may be made of the stand per acre before and after the first cutting from the cruise figures for the plot given in table 2.

TABLE 2

Stand Per Acre of Forest Service Permanent Sample Plot, Before and After Cutting 'Trees 11.6 Inches in Diameter and Over

\begin{tabular}{|c|c|c|c|c|c|c|}
\hline \multirow{2}{*}{ Species } & \multirow{2}{*}{$\begin{array}{l}\text { Original } \\
\text { stand, } \\
\text { trees per } \\
\text { acre }\end{array}$} & \multicolumn{2}{|c|}{ Trees left } & \multirow{2}{*}{$\begin{array}{l}\text { Original } \\
\text { volume, } \\
\text { board } \\
\text { measure }\end{array}$} & \multicolumn{2}{|c|}{ Volume left } \\
\hline & & Number & Per cent & & $\begin{array}{c}\text { Board } \\
\text { measure }\end{array}$ & Per cent \\
\hline Western yellow pine & 15.40 & 10.85 & 70.5 & 29,130 & 14,070 & 48.3 \\
\hline Sugar pine & 2.85 & 1.65 & 57.9 & 11,780 & 4,670 & 39.7 \\
\hline White fir. & 2.00 & 0.70 & 35.0 & 5,070 & 230 & 4.5 \\
\hline Incense cedar...... & 5.30 & 2.20 & 41.5 & 5,800 & 670 & 11.5 \\
\hline Total & 25.55 & 15.40 & 60.2 & 51,780 & 19,640 & 37.9 \\
\hline
\end{tabular}

\section{THE BASIC DATA}

A partial stem analysis was made of each western yellow pine tree as felled and bucked in 1928, both virgin and cut-over, by measuring and plotting in the field on United States Forest Service 
form 558a the following data: (1) diameter at breast height outside bark; (2) diameter outside and inside bark in 1928, and diameter inside bark at the end of the 1909 growing season, at stump and at each $\log$ length of usually 16.3 feet; and (3) total height in 1928 and in 1909.

TABLE 3

SuMmary of Basic Data

\begin{tabular}{|c|c|c|}
\hline \multirow[b]{2}{*}{ Tree class } & \multicolumn{2}{|c|}{ Number of trees } \\
\hline & $\begin{array}{l}\text { From } \\
\text { virgin } \\
\text { stand }\end{array}$ & $\begin{array}{l}\text { From } \\
\text { cut-over } \\
\text { stand }\end{array}$ \\
\hline 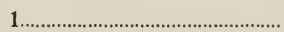 & 40 & 20 \\
\hline 2 & 43 & 3 \\
\hline 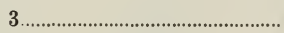 & 74 & 25 \\
\hline 4 & 49 & 25 \\
\hline 5 & 40 & 14 \\
\hline 6 & 30 & 8 \\
\hline 7 & 17 & 17 \\
\hline Total...... & 293 & 112 \\
\hline
\end{tabular}

Tree class by Dunning' $\mathrm{s}^{4}$ classification was also recorded. Table 3 summarizes the data by tree class. In order to visualize the tree classes as encountered in a selection forest of western yellow pine, the description and typical form of each class, taken from Dunning's paper, is here reproduced:

Seven classes are proposed, as follows [see fig. 1]:

Class 1: Age class, young or thrifty mature (up to 150 years) ; position, isolated or dominant (rarely codominant); crown length, 65 per cent or more of the total height; crown width, average or wider; form of top, pointed; vigor, good.

Trees of this class are rarely over 30 inches in diameter even on good sites. The bark is dark brown and roughly fissured into ridges or small plates. The foliage is rich green in color and dense, owing to retention of the needles of three to five seasons or more, except at the base of the crown. The needles are often long and coarse, especially near the top. Terminal buds are large. The top is pointed, owing to the rapid elongation of the terminal. Thrifty open-grown young trees belonging to this class are, however, sometimes round topped because of excessive lateral growth of branches near the top. On the other hand, slowgrowing trees sometimes have pointed tops, due to weak development of laterals. The annual whorls of branches and internodes are still distinct, except in the lower crown. Branches are horizontal or upward curving, except at the base of the crown where suppression is taking place. Numerous stubs of dead branches are likely to be present below the crown.

4 Dunning, Duncan. A tree classification for the selection forests of the Sierra Nevada. Jour. Agr. Research 36:755-771. 1928. 
Class 2: Age class, young or thrifty mature (up to 150 years); position, usually codominant (rarely isolated or dominant); crown length, less than 65 per cent of the total height; crown width, average or narrower; form of top, pointed; vigor, good or moderate.

Such trees are usually less than 24 inches in diameter. They are commonly the inside codominant trees of groups. The crowns are smaller and less dense than in trees of the first type. Otherwise they are similar to those of class 1 .

Class 3: Age class, mature (150-300 years); position, isolated or dominant (rarely codominant); crown length, 65 per cent or more of total height; crown width, average or wider; form of top, round; vigor, moderate.

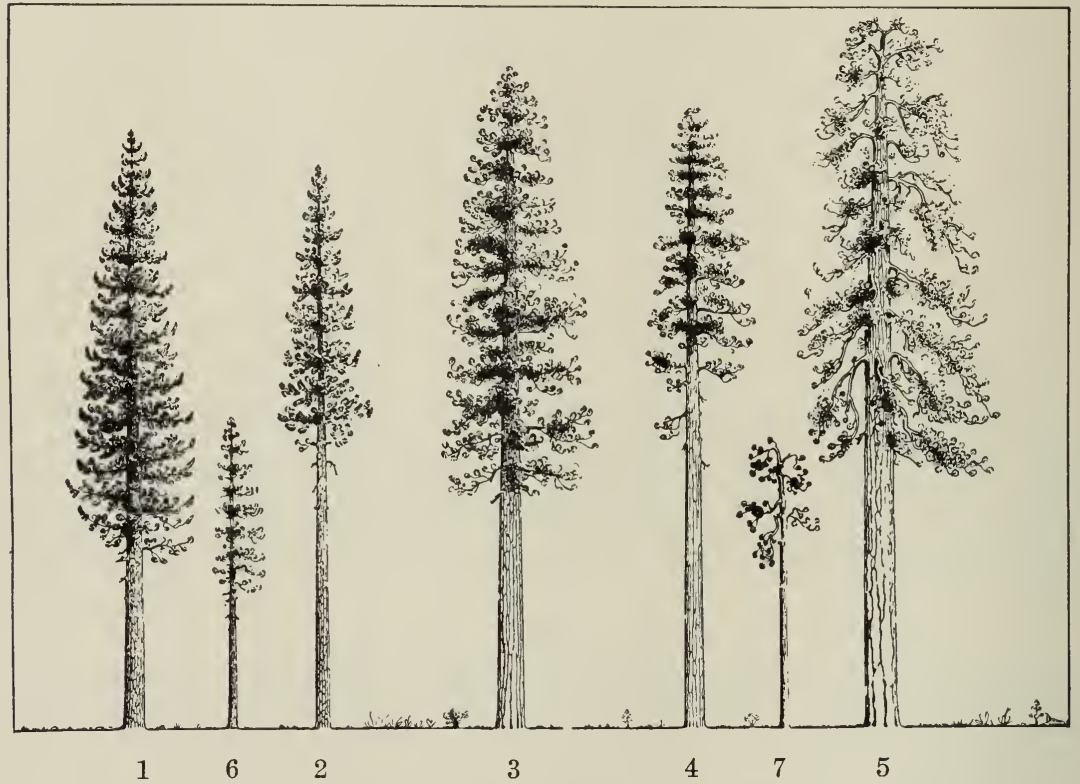

Fig. 1.-Tree classes of western yellow pine. (After Dunning.)

These trees are ordinarily between 18 and 40 inches in diameter, depending on site quality. The bark is light brown or yellow, with moderately large smooth plates. The foliage is less dense than in class 1 trees. The top is round, because of slow height growth. The nodes are indistinct, because of incomplete whorls of branches. The branches are nearly all horizontal or drooping.

Class 4: Age class, mature (150-300 years); position, usually codominant (rarely isolated or dominant); crown length, less than 65 per cent of the total height; crown width, average or narrower; form of top, round; vigor, moderate or poor.

These are commonly the inside or codominant trees of this age class. Except for their small, poorly developed crowns and smaller size, they are similar to class 3 trees. 
Class 5: Age class, overmature (over 300 years) ; position, isolated or dominant (rarely codominant); crown, of any size; form of top, flat; vigor, poor.

These are usually the largest trees in the stand. The bark is light yellow in color, the plates often very wide, long and smooth, especially near the base. The bark may be thin, having weathered more rapidly than it has grown. The foliage is usually rather pale green and very thin. The needles are fairly short, appearing as tufts on the ends of the twigs. The needles of two or three seasons only may be retained, even near the top. The top is flat, the terminal rarely discernible. There is no appreciable elongation of the main axis. Scarcely any nodes are distinguishable. Nearly all the branches are drooping, gnarled, and crooked.

Class 6: Age class, young or thrifty mature (up to 150 years) ; position, intermediate or suppressed; crown, of any size, usually small; form of top, round or pointed; vigor, moderate or poor.

These are understory trees, rarely over 12 or 14 inches in diameter. The bark is dark and rough. The top is round or pointed, showing that some height growth is taking place. Whorls of branches are evident, though the internodes are short.

Class 7: Age class, mature or overmature (over 150 years); position, interme. diate or suppressed; orown, of any size, usually small; form of top, flat; vigor, poor.

These understory trees are rarely over 18 inches in diameter. The bark is light in color, thin, and smooth. The top is flat, the terminal rarely distinguishable. The foliage is excessively thin. The few branches present are gnarled and drooping.

After several hours of personal instruction by Mr. Dunning, combined with a little practice, the four students who measured and recorded the data became very proficient in classifying the trees, seldom indeed disagreeing on the class of any individual tree.

\section{RESULTS OF THE INVESTIGATION}

The data from the cut-over stand were compared with those from the virgin stand, (1) by volume for trees of the same sizes, (2) by taper inside bark, and (3) by diameter growth along the stem between 1910 and 1928.

Such comparisons should be legitimate because (1) site quality is broadly the same in both stands, Site I for western yellow pine, and (2) both stands originally contained about the same volume on the acre basis, between 50 and 60 thousand feet board measure.

\section{COMPARISON BY VOLUME BOARD MEASURE}

The removal of 40 per cent of the number of merchantable trees from a virgin selection stand of western yellow pine, even though they contain 60 per cent of the volume board measure, does not result in 
mensurational changes in the remaining trees sufficiently definite, after 18 years, to warrant separate volume tables for the residual stand.

This conclusion was reached after checking the actual volumes of the trees taken from the virgin and cut-over stands against the United States Forest Service general volume table for western yellow pine, Site I. Aggregate tree volumes expressed as percentage difference from the corresponding aggregate tabular volumes are as follows:

For 285 trees from the virgin stand, +6.3 per cent.

For 110 trees from the eut-over stand, +5.8 per cent. Detailed analyses of volume relations are given on pages 13 to 16 .

\section{COMPARISON BY TAPER}

Diameter inside bark at each tenth of stem height was correlated with the tenth of height at which the diameter measurement was taken, with diameter breast high inside bark, with height of tree, and with tree class.

On the basis of this part of the investigation, taper tables for the species on Site I were constructed. Contrary to hypothesis, the form of the trees from the cut-over stand in 1928, after 18 years of growth under released conditions, does not differ significantly from the form of the trees grown under virgin conditions, that is, from the relative 1909 tapers of the trees from the cut-over stand and the relative 1909 and 1928 tapers of the trees from the virgin stand. Hence the inside bark tapers presented (table 4) are based upon the average of the four sets.

Bark thickness at breast height of the eut-over stand was found to be about 8 per cent less than that of the virgin stand; hence the inside bark diameters at breast height of table 4 are based upon bark thickness of the trees from the virgin stand only. Therefore the taper tables strictly apply only to virgin western yellow pine.

Table 5 gives the corrections to be added to the values of table 4 , to obtain taper by tree class.

Methods of making detailed analysis of tree taper from the basic data are explained on page 17. 


\section{TABLE 4}

Per Cent Taper of Western Yellow Pine, Site Quality I, Average of All Tree Classes*

\begin{tabular}{c|c|c|c|c|c|c|c|c|c|c|c|c}
\hline \hline & \multicolumn{6}{|c}{ Per cent length from breast-height to tip } \\
\cline { 2 - 6 } $\begin{array}{c}\text { Diameter } \\
\text { breast high } \\
\text { outside bark, } \\
\text { in inches }\end{array}$ & $\begin{array}{c}\text { Diameter } \begin{array}{c}\text { Diast high } \\
\text { inside bark, } \\
\text { in inches }\end{array}\end{array}$ & 0 & 10 & 20 & 30 & 40 & 50 & 60 & 70 & 80 & 90 & 100 \\
\cline { 3 - 7 } & Diameter inside bark in per cent of diameter breast high inside bark \\
\hline
\end{tabular}

Total height of tree, 40 feet

\begin{tabular}{r|r|r|r|r|r|r|r|r|r|r|r|r}
\hline 8 & 6.7 & 100.0 & 91.2 & 83.1 & 76.9 & 69.6 & 61.7 & 54.1 & 45.9 & 35.3 & 21.9 & 0 \\
12 & 10.2 & 100.0 & 91.2 & 83.1 & 76.9 & 69.7 & 61.8 & 54.3 & 46.1 & 35.5 & 22.0 & 0 \\
16 & 13.6 & 100.0 & 91.2 & 83.1 & 76.9 & 69.7 & 62.0 & 54.5 & 46.4 & 35.7 & 22.1 & 0 \\
\hline
\end{tabular}

Total height of tree, 60 feet

\begin{tabular}{r|r|r|r|r|r|r|r|r|r|r|r|r}
\hline 8 & 6.7 & 100.0 & 91.4 & 83.8 & 77.9 & 70.7 & 62.8 & 55.0 & 46.2 & 35.3 & 21.9 & 0 \\
12 & 10.2 & 100.0 & 91.4 & 83.8 & 77.9 & 70.8 & 62.9 & 55.2 & 46.4 & 35.5 & 22.0 & 0 \\
16 & 13.6 & 100.0 & 91.4 & 83.8 & 77.9 & 70.8 & 63.1 & 55.4 & 46.7 & 35.7 & 22.1 & 0 \\
20 & 17.1 & 100.0 & 91.4 & 83.8 & 77.9 & 70.9 & 63.2 & 55.6 & 46.9 & 35.9 & 22.2 & 0 \\
\hline
\end{tabular}

Total height of tree, 80 feet

\begin{tabular}{r|r|r|r|r|r|r|r|r|r|r|r|r}
\hline 8 & 6.7 & 100.0 & 91.5 & 84.5 & 78.9 & 71.9 & 64.0 & 55.8 & 46.6 & 34.8 & 21.9 & 0 \\
12 & 10.2 & 100.0 & 91.5 & 84.5 & 78.9 & 72.0 & 64.1 & 56.0 & 46.8 & 35.0 & 22.0 & 0 \\
16 & 13.6 & 100.0 & 91.5 & 84.5 & 78.9 & 72.0 & 64.3 & 56.2 & 47.1 & 35.2 & 22.1 & 0 \\
20 & 17.1 & 100.0 & 91.5 & 84.5 & 78.9 & 72.0 & 64.4 & 56.4 & 47.3 & 35.4 & 22.2 & 0 \\
24 & 20.8 & 100.0 & 91.5 & 84.5 & 78.9 & 72.0 & 64.5 & 56.6 & 47.5 & 35.6 & 22.3 & 0 \\
28 & 24.5 & 100.0 & 91.5 & 84.5 & 78.9 & 72.0 & 64.6 & 56.8 & 47.8 & 35.8 & 22.5 & 0 \\
32 & 28.3 & 100.0 & 91.5 & 84.5 & 78.9 & 72.0 & 64.8 & 57.1 & 48.1 & 36.0 & 22.6 & 0 \\
\hline
\end{tabular}

Total height of tree, 100 feet

\begin{tabular}{l|l|l|l|l|l|l|l|l|l|l|l|l}
\hline 12 & 10.2 & 100.0 & 91.6 & 85.2 & 80.0 & 73.2 & 65.3 & 56.9 & 47.2 & 35.6 & 22.0 & 0 \\
16 & 13.6 & 100.0 & 91.6 & 85.2 & 80.0 & 73.2 & 65.5 & 57.1 & 47.5 & 35.8 & 22.1 & 0 \\
20 & 17.1 & 100.0 & 91.6 & 85.2 & 80.0 & 73.3 & 65.6 & 57.3 & 47.7 & 36.0 & 22.2 & 0 \\
24 & 20.8 & 100.0 & 91.6 & 85.2 & 80.0 & 73.3 & 65.7 & 57.5 & 47.9 & 36.2 & 22.3 & 0 \\
28 & 24.5 & 100.0 & 91.6 & 85.2 & 80.0 & 73.3 & 65.8 & 57.7 & 48.2 & 36.4 & 22.5 & 0 \\
32 & 28.3 & 100.0 & 91.6 & 85.2 & 80.0 & 73.3 & 66.0 & 58.0 & 48.5 & 36.6 & 22.6 & 0 \\
36 & 32.1 & 100.0 & 91.6 & 85.2 & 80.0 & 73.3 & 66.1 & 58.2 & 48.7 & 36.9 & 22.7 & 0 \\
40 & 35.9 & 100.0 & 91.6 & 85.2 & 80.0 & 73.4 & 66.3 & 58.4 & 49.0 & 37.1 & 22.9 & 0 \\
\hline
\end{tabular}

Total height of tree, 120 feet

\begin{tabular}{l|l|l|l|l|l|l|l|l|l|l|l|l}
\hline 12 & 10.2 & 100.0 & 91.7 & 85.9 & 81.0 & 74.4 & 66.5 & 57.7 & 47.6 & 35.7 & 22.0 & 0 \\
16 & 13.6 & 100.0 & 91.7 & 85.9 & 81.0 & 74.4 & 66.7 & 57.9 & 47.9 & 35.9 & 22.1 & 0 \\
20 & 17.1 & 100.0 & 91.7 & 85.9 & 81.0 & 74.5 & 66.8 & 58.1 & 48.1 & 36.1 & 22.2 & 0 \\
24 & 20.8 & 100.0 & 91.7 & 85.9 & 81.0 & 74.5 & 66.9 & 58.3 & 48.3 & 36.3 & 22.3 & 0 \\
28 & 24.5 & 100.0 & 91.7 & 85.9 & 81.0 & 74.5 & 67.0 & 58.5 & 48.6 & 36.5 & 22.5 & 0 \\
32 & 28.3 & 100.0 & 91.7 & 85.9 & 81.0 & 74.5 & 67.2 & 58.8 & 48.9 & 36.7 & 22.6 & 0 \\
36 & 32.1 & 100.0 & 91.7 & 85.9 & 81.0 & 74.5 & 67.3 & 59.0 & 49.1 & 37.0 & 22.7 & 0 \\
40 & 35.9 & 100.0 & 91.7 & 85.9 & 81.0 & 74.6 & 67.5 & 59.2 & 49.4 & 37.2 & 22.9 & 0 \\
44 & 39.7 & 100.0 & 91.7 & 85.9 & 81.0 & 74.6 & 67.6 & 59.4 & 49.6 & 37.4 & 23.0 & 0 \\
\hline
\end{tabular}

Total height of tree, 140 feet

\begin{tabular}{l|l|l|l|l|l|l|l|l|l|l|l|l}
\hline 16 & 13.6 & 100.0 & 91.8 & 86.6 & 82.1 & 75.6 & 67.9 & 58.8 & 48.3 & 35.9 & 22.1 & 0 \\
20 & 17.1 & 100.0 & 91.8 & 86.6 & 82.1 & 75.7 & 68.0 & 59.0 & 48.5 & 36.1 & 22.2 & 0 \\
24 & 20.8 & 100.0 & 91.8 & 86.6 & 82.1 & 75.7 & 68.1 & 59.2 & 48.7 & 36.3 & 22.3 & 0 \\
28 & 24.5 & 100.0 & 91.8 & 86.6 & 82.1 & 75.7 & 68.2 & 59.4 & 49.0 & 36.5 & 22.5 & 0 \\
\hline
\end{tabular}

* Taper figures are averages of 1909 and 1928 figures from both virgin and cut-over stands.

$\dagger$ Based on bark thickness of trees from virgin stand only. 
TABLE 4-(Continued)

\begin{tabular}{|c|c|c|c|c|c|c|c|c|c|c|c|c|}
\hline \multirow{3}{*}{$\begin{array}{c}\text { Diameter } \\
\text { breast high } \\
\text { outside bark, } \\
\text { in inches }\end{array}$} & \multirow{3}{*}{$\begin{array}{c}\text { Diameter } \\
\text { breast high } \\
\text { inside bark, } \\
\text { in inches } \dagger\end{array}$} & \multicolumn{11}{|c|}{ Per cent length from breast-height to tip } \\
\hline & & 0 & 10 & 20 & 30 & 40 & 50 & 60 & 70 & 80 & 90 & 100 \\
\hline & & \multicolumn{11}{|c|}{ Diameter inside bark in per cent of diameter breast high inside bark } \\
\hline \multicolumn{13}{|c|}{ Total height of tree, 140 feet (continued) } \\
\hline 32 & 28.3 & 100.0 & 91.8 & 86.6 & 82.1 & 75.7 & 68.4 & 59.7 & 49.3 & 36.7 & 22.6 & 0 \\
\hline 36 & 32.1 & 100.0 & 91.8 & 86.6 & 82.1 & 75.7 & 68.5 & 59.9 & 49.5 & 37.0 & 22.7 & 0 \\
\hline 40. & 35.9 & 100.0 & 91.8 & 86.6 & 82.1 & 75.8 & 68.7 & 60.1 & 49.8 & 37.2 & 22.9 & 0 \\
\hline 44 & 39.7 & 100.0 & 91.8 & 86.6 & 82.1 & 75.8 & 68.8 & 60.3 & 50.0 & 37.4 & 23.0 & 0 \\
\hline 48 & 43.5 & 100.0 & 91.8 & 86.6 & 82.1 & 75.8 & 68.9 & 60.5 & 50.3 & 37.6 & 23.1 & 0 \\
\hline 52 & 47.3 & 100.0 & 91.8 & 86.6 & 82.1 & 75.9 & 69.1 & 60.7 & 50.5 & 37.8 & 23.2 & 0 \\
\hline
\end{tabular}

Total height of tree, 160 feet

\begin{tabular}{l|l|l|l|l|l|l|l|l|l|l|l|l}
\hline 24 & 20.8 & 100.0 & 91.9 & 87.3 & 83.1 & 76.9 & 69.3 & 60.0 & 49.1 & 36.3 & 22.3 & 0 \\
28 & 24.5 & 100.0 & 91.9 & 87.3 & 83.1 & 76.9 & 69.4 & 60.2 & 49.4 & 36.5 & 22.5 & 0 \\
32 & 28.3 & 100.0 & 91.9 & 87.3 & 83.1 & 76.9 & 69.6 & 60.5 & 49.7 & 36.7 & 22.6 & 0 \\
36 & 32.1 & 100.0 & 91.9 & 87.3 & 83.1 & 76.9 & 69.7 & 60.7 & 49.9 & 37.0 & 22.7 & 0 \\
40 & 35.9 & 100.0 & 91.9 & 87.3 & 83.1 & 77.0 & 69.9 & 60.9 & 50.2 & 37.2 & 22.9 & 0 \\
44 & 39.7 & 100.0 & 91.9 & 87.3 & 83.1 & 77.0 & 70.0 & 61.1 & 50.4 & 37.4 & 23.0 & 0 \\
48 & 43.5 & 100.0 & 91.9 & 87.3 & 83.1 & 77.0 & 70.1 & 61.3 & 50.7 & 37.6 & 23.1 & 0 \\
52 & 47.3 & 100.0 & 91.9 & 87.3 & 83.1 & 77.1 & 70.3 & 61.5 & 50.9 & 37.8 & 23.2 & 0 \\
56 & 51.1 & 100.0 & 91.9 & 87.3 & 83.1 & 77.1 & 70.4 & 61.8 & 51.2 & 38.0 & 23.3 & 0 \\
\hline
\end{tabular}

Total height of tree, 180 feet

\begin{tabular}{l|l|l|l|l|l|l|l|l|l|l|l|l}
\hline 32 & 28.3 & 100.0 & 92.0 & 87.9 & 84.1 & 78.0 & 70.7 & 61.4 & 500 & 37.0 & 22.6 & 0 \\
36 & 32.1 & 100.0 & 92.0 & 87.9 & 84.1 & 78.0 & 70.8 & 61.6 & 50.2 & 37.1 & 22.7 & 0 \\
40 & 35.9 & 100.0 & 92.0 & 87.9 & 84.1 & 78.1 & 71.0 & 61.8 & 50.5 & 37.3 & 22.9 & 0 \\
44 & 39.7 & 100.0 & 92.0 & 87.9 & 84.1 & 78.1 & 71.1 & 62.0 & 50.7 & 37.5 & 23.0 & 0 \\
48 & 43.5 & 100.0 & 92.0 & 87.9 & 84.1 & 78.1 & 71.2 & 62.2 & 51.0 & 37.7 & 23.1 & 0 \\
52 & 47.3 & 100.0 & 92.0 & 87.9 & 84.1 & 78.2 & 71.4 & 62.4 & 51.2 & 37.9 & 23.2 & 0 \\
56 & 51.1 & 100.0 & 92.0 & 87.9 & 84.1 & 78.2 & 71.5 & 62.7 & 51.5 & 38.1 & 23.3 & 0 \\
60 & 54.9 & 100.0 & 92.0 & 87.9 & 84.1 & 78.3 & 71.7 & 62.9 & 51.7 & 38.4 & 23.4 & 0 \\
64 & 58.6 & 100.0 & 92.0 & 87.9 & 84.1 & 78.3 & 71.8 & 63.1 & 52.0 & 38.6 & 23.6 & 0 \\
68 & 62.4 & 100.0 & 92.0 & 87.9 & 84.1 & 78.3 & 71.9 & 63.3 & 52.2 & 38.8 & 23.7 & 0 \\
72 & 66.2 & 100.0 & 92.0 & 87.9 & 84.1 & 78.4 & 72.1 & 63.6 & 52.4 & 39.0 & 23.8 & 0 \\
\hline
\end{tabular}

Total height of tree, 200 feet

\begin{tabular}{l|l|l|l|l|l|l|l|l|l|l|l|l}
\hline 44 & 39.7 & 100.0 & 92.1 & 88.6 & 85.1 & 79.3 & 72.3 & 62.9 & 51.1 & 37.5 & 23.0 & 0 \\
48 & 43.5 & 100.0 & 92.1 & 88.6 & 85.1 & 79.3 & 72.4 & 63.1 & 51.4 & 37.7 & 23.1 & 0 \\
52 & 47.3 & 100.0 & 92.1 & 88.6 & 85.1 & 79.4 & 72.6 & 63.3 & 51.6 & 37.9 & 23.2 & 0 \\
56 & 51.1 & 100.0 & 92.1 & 88.6 & 85.1 & 79.4 & 72.7 & 63.6 & 51.9 & 38.1 & 23.3 & 0 \\
60 & 54.9 & 100.0 & 92.1 & 88.6 & 85.1 & 79.5 & 72.9 & 63.8 & 52.1 & 38.4 & 23.4 & 0 \\
64 & 58.6 & 100.0 & 92.1 & 88.6 & 85.1 & 79.5 & 73.0 & 64.0 & 52.4 & 38.6 & 23.6 & 0 \\
68 & 62.4 & 100.0 & 92.1 & 88.6 & 85.1 & 79.5 & 73.1 & 64.2 & 52.6 & 38.8 & 23.7 & 0 \\
72 & 66.2 & 100.0 & 92.1 & 88.6 & 85.1 & 79.6 & 73.3 & 64.5 & 52.8 & 39.0 & 23.8 & 0 \\
76 & 70.0 & 100.0 & 92.1 & 88.6 & 85.1 & 79.6 & 73.4 & 64.7 & 53.1 & 39.2 & 23.9 & 0 \\
\hline
\end{tabular}

Total height of tree, 220 feet

\begin{tabular}{l|l|l|l|l|l|l|l|l|l|l|l|l}
\hline 56 & 51.1 & 100.0 & 92.2 & 89.4 & 86.2 & 80.6 & 73.9 & 64.4 & 52.2 & 38.2 & 23.3 & 0 \\
60 & 54.9 & 100.0 & 92.2 & 89.4 & 86.2 & 80.7 & 74.1 & 64.6 & 52.4 & 38.5 & 23.4 & 0 \\
64 & 58.6 & 100.0 & 92.2 & 89.4 & 86.2 & 80.7 & 74.2 & 64.8 & 52.7 & 38.7 & 23.6 & 0 \\
68 & 62.4 & 100.0 & 92.2 & 89.4 & 86.2 & 80.7 & 74.3 & 65.0 & 52.9 & 38.9 & 23.7 & 0 \\
72 & 66.3 & 100.0 & 92.2 & 89.4 & 86.2 & 80.8 & 74.5 & 65.3 & 53.1 & 39.1 & 23.8 & 0 \\
76 & 70.0 & 100.0 & 92.2 & 89.4 & 86.2 & 80.8 & 74.6 & 65.5 & 53.4 & 39.3 & 23.9 & 0 \\
\hline
\end{tabular}

* Taper figures are averages of 1909 and 1928 figures from both virgin and cut-over stands.

$\dagger$ Based on bark thickness of trees from virgin stand only. 
TABLE 5

Deviation of Percentage Diameters (Taper) by Tree Class From the Average for All Classes Combined*

\begin{tabular}{|c|c|c|c|c|c|c|c|c|c|c|c|}
\hline \multirow{3}{*}{$\begin{array}{l}\text { Tree } \\
\text { class }\end{array}$} & \multicolumn{11}{|c|}{ Per cent length from breast-height to tip } \\
\hline & 0 & 10 & 20 & 30 & 40 & 50 & 60 & 70 & 80 & 90 & 100 \\
\hline & \multicolumn{11}{|c|}{ Deviation of percentage diameters from the average for all classes combined } \\
\hline 1 & 0 & 0 & 0 & 0 & 0 & -0.5 & -2.0 & -3.9 & -3.8 & -2.9 & 0 \\
\hline 2 & 0 & -0.5 & -0.9 & -1.2 & -1.2 & -1.3 & -1.3 & -1.2 & -0.9 & $-0.6^{\circ}$ & 0 \\
\hline 3 & 0 & -0.4 & -0.8 & -1.2 & -1.6 & -2.0 & -2.5 & -3.2 & -3.5 & -3.2 & 0 \\
\hline 4 & 0 & -0.8 & -1.1 & -0.7 & +0.2 & +1.3 & +2.8 & +2.8 & +1.6 & +0.2 & 0 \\
\hline 5 & 0 & +1.0 & +1.0 & +1.2 & +1.6 & +2.5 & $\begin{array}{r}+3.9 \\
\end{array}$ & +5.4 & +6.2 & +6.1 & 0 \\
\hline 6 & 0 & +1.0 & +1.4 & +1.1 & -0.5 & -1.6 & -2.1 & -2.1 & -1.5 & 0 & 0 \\
\hline 7 & 0 & +1.0 & +2.3 & +3.9 & +5.5 & +7.5 & +10.0 & +11.9 & +12.8 & +12.4 & 0 \\
\hline
\end{tabular}

* To be added to the values of table 4 for taper curves by tree class.

\section{COMPARISON BY DIAMETER GROWTH ALONG THE STEMS}

By definition, the following relation exists in the basic data:

$D_{1928}=D_{1909}+\triangle_{1910-1928}$ in which $D_{1909}$ is the diameter in inches at any point along the stem in $1909, D_{1928}$ is the diameter at the same point in 1928, and $\triangle_{1910-1928}$ is the diameter growth at that point during the time interval.

The analysis of the tapers discloses that for trees of the same tree class, total height, and diameter breast high, there is no significant difference in the relative values of either $D_{1909}$ or $D_{1928}$ - that is, in taper-between the trees from the virgin and cut-over stand. But $D_{1909}$ and $D_{1928}$ are large in comparison with $\triangle_{1910-1928}$, and their very dimensions may entirely overshadow the relatively small though significant differences in $\triangle_{1910-1928}$ following partial cutting in the virgin stand.

On this account the diameter growth at ten equidistant points along the stem of the trees from the cut-over stand was compared with the the diameter growth at the same relative points along the stems of the trees from the virgin stand.

Figure 2 portrays graphically the final results by tree class. The excess of periodic diameter growth of the cut-over stand over that of the virgin represents the acceleration of diameter growth for constant height growth, following a selection cutting 18 years before. Classes 1 , 3 , and 5-the dominant trees in their respective age groups-show the greatest acceleration, whereas classes 2 and 4 -the codominantsshow comparatively little. The acceleration in class 6 is least, but the growth before release is exceeded only by that of class 1 . The ability of 

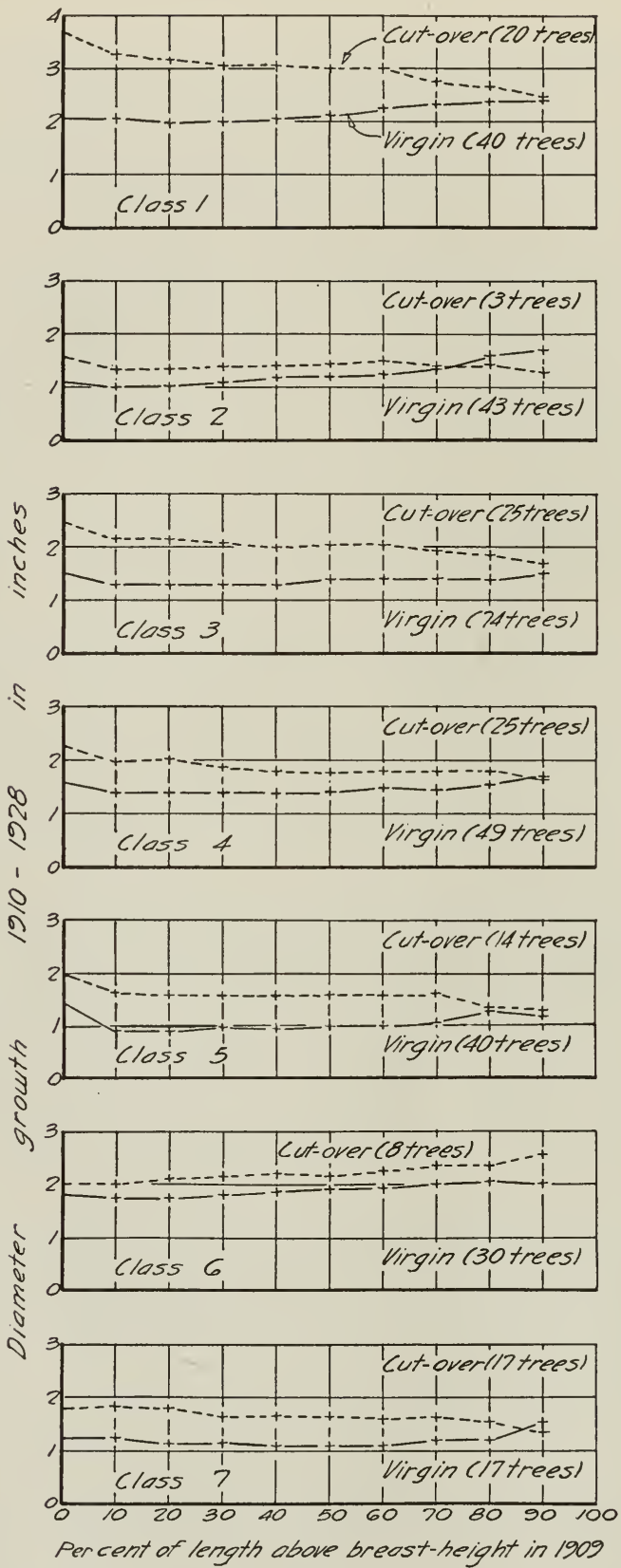

Fig. 2.-Comparison of diameter growth along the stem by tree class. The difference between the two sets of values in each class is the increased diameter growth 18 years after partial logging, provided that logging does not influence height growth. 
the species to recover from suppression is well exemplified by the relative growth rates of the old, suppressed class 7 . That this recovery is apparently not so great in class 2 may, perhaps, be due simply to scarcity of data.

\section{DETAILED ANALYSIS OF THE DATA}

\section{TREE VOLUMES}

Volumes of the basic tree data were checked against the United States Forest Service general volume table for western yellow pine. It is obvious that any standard table would serve as the base for analyzing volume ratios between the virgin and cut-over stands. The general volume table was selected because this investigation afforded the first chance of checking it with California data; and pending such checks throughout the commercial range of western yellow pine in the United States, the table is still on trial.

The board-foot volume of each tree cut in 1928 was compared to its tabular volume for diameter and height, and its percentage difference computed. For 285 trees from the virgin stand, the mean and standard deviation of the percentage differences are as follows :

Mean difference $=+6.3$ per cent.

Standard deviation $=15.7$ per cent.

For 110 trees of the cut-over stand, the corresponding values are :

Mean difference $=+9.8$ per cent.

Standard deviation $=14.4$ per cent.

The comparison of the mean differences with their standard errors casts doubt that the trees from the two stands may be considered as samples of the same material. The reliability of the difference between two means is based upon the standard error of the difference in the following measure :

$$
M_{1}-M_{2} \pm \sqrt{\frac{\sigma_{1}^{2}}{N_{1}}+\frac{\sigma_{2}^{2}}{N_{2}}}
$$

in which $M=$ the mean difference, $\sigma=$ the standard deviation of the individual differences, $N=$ the number of trees, and subscripts 1 and 2 refer to the cut-over and the virgin stands respectively. When the values obtained in this study are substituted, the following equation is obtained:

$$
9.8-6.3 \pm \sqrt{\frac{(14.4)^{2}}{110}+\frac{(15.7)^{2}}{285}}
$$

or $3.5 \pm 1.68$ per cent. 
Hence the difference between the volume ratios is about twice the standard error of the difference-just enough to raise doubt as to the homogeneity of the two stands; this, in turn, suggests further analysis.

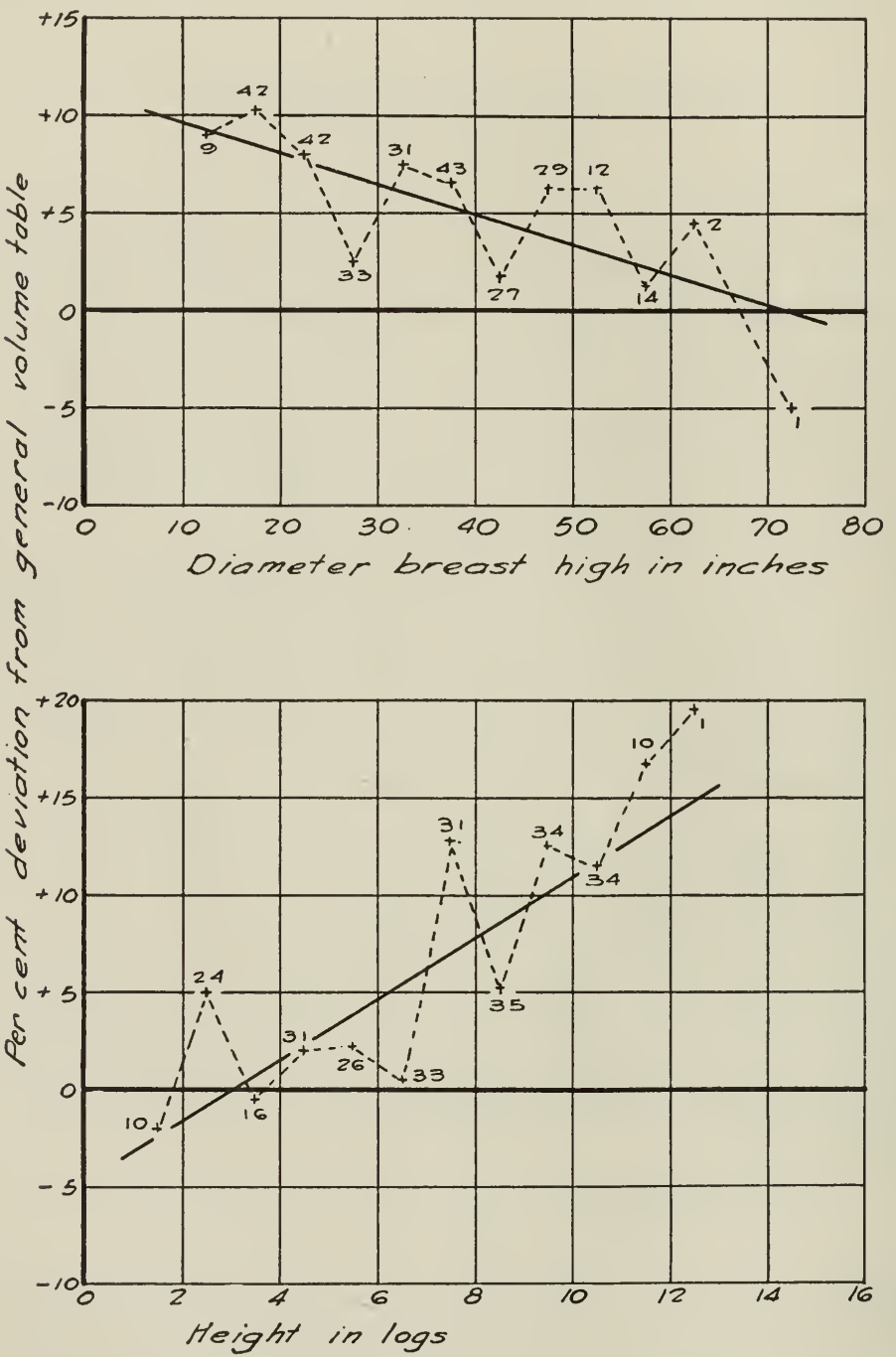

Fig. 3.-Comparison of tree volumes from the virgin stand with the United States Forest Service general volume table. Residual volumes in percentages are plotted as deviations from the net regression slopes.

The percentage differences were next correlated with diameter and height. For the trees from the virgin stand, the multiple correlation coefficient, $r_{1.23}=0.158 \pm 0.058$, showing a very weak relation. For 

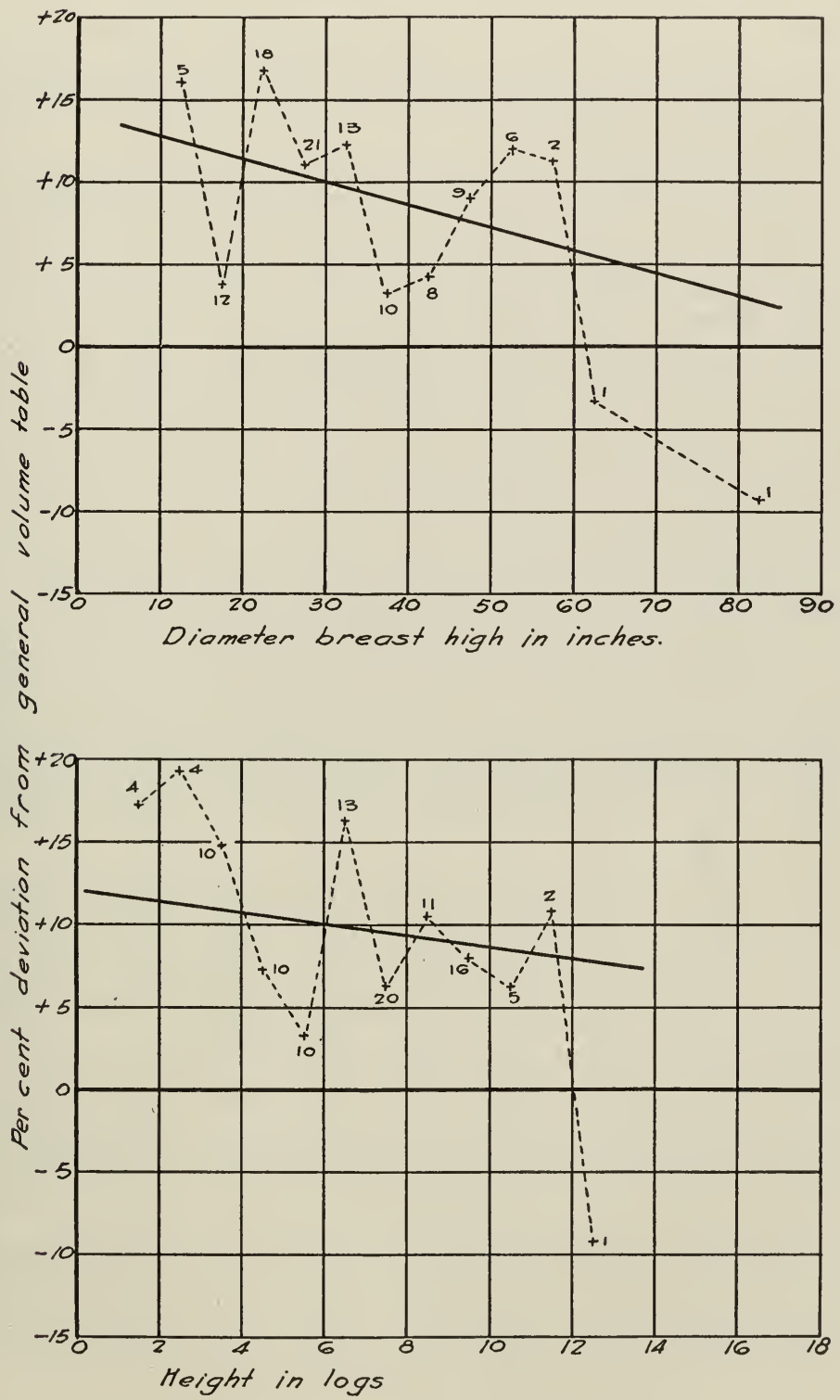

Fig. 4.-Comparison of tree volumes from the cut-over stand with the United States Forest Service general volume table. Residual volumes in percentages are plotted as deviations from the net regression slopes. 
the trees from the cut-over stand $r_{1.23}=0.214 \pm 0.093$, likewise indicating the practical independence of volume differences to diameter and height. In figures 3 and 4 are plotted the deviations from the multiple regression equation by diameter with average height, and by height with average diameter, for the trees from the virgin and cut-over stands respectively.

The aggregate difference of tree volumes from corresponding tabular volumes in the case of the data from the virgin stand is the same as the mean of the percentage differences, viz., +6.3 per cent. ${ }^{5}$ But the aggregate difference of the trees from the cut-over stand is +5.8 per cent-4 per cent lower than 9.8 , the mean difference of the percentages. Figures 3 and 4 explain the discrepancy. For the trees from the virgin stand, volume differences tend to decrease with increasing diameter, but to increase with increasing height, the summation of the two making the mean difference of the percentages equal to the aggregate difference in percentage.

For the trees from the cut-over stand, however, volume differences tend to decrease with increase in both diameter and height. As the large trees carry the preponderance of volume, the aggregate difference is naturally lower than the mean of the percentage differences. In other words, aggregate difference is based upon weighting the trees by volume, and mean difference is based upon giving equal weight to each tree regardless of size.

Volume table checks are practically always made by considering aggregate differences only. But when the mean of the percentage differences is also given, accompanied by the correlation of deviations with tree size, a clearer picture of the check is obtained. The aggregate difference, if used alone, would have indicated that there was no difference between the volume of the trees from the two stands. But the downward tendency of the net regression line with height in the case of the cut-over trees and its upward tendency in the case of the trees from the virgin stand, immediately suggest that there are factors which would make for volume differences if they were not compensating. These factors seem to be (1) greater acceleration of wood growth at breast height after release than at any other point along the stem, and (2) retardation of bark growth at breast height after release. ${ }^{6}$

5 See page 13.

6 Compare figure $11 D$ with figure $12 D$ for relative wood growth at breast height.

In bark thickness at breast height, as stated on page 24 , the trees taken from the cut-over stand averaged about 8 per cent less, throughout the range of diameters encountered, than those from the virgin stand. 


\section{TREE TAPERS}

The 1909 and 1928 taper curve of each tree-plotted in the field on Forest Service form 558a at the time the stem analyses were taken in 1928-was divided into ten sections of equal length from breast height to the tip; and for purposes of better comparison between large and small trees, section heights were translated to percentage of total height above breast height, and section diameters inside bark to percentage of diameter at breast height inside bark. The example of table 6 may serve to clarify the procedure used. Section heights of the 1909 stem of this sample tree are at 8.30-foot intervals, and for the 1928 stem at 10.75 -foot intervals from breast height.

\section{TABLE 6}

Translation of Taper Measurements in Inches to Percentile Taper Measurements for Tree Number $66,{ }^{*}$ Class 1 , Virgin Stand

\begin{tabular}{|c|c|c|c|c|c|}
\hline \multicolumn{3}{|c|}{1909 Taper } & \multicolumn{3}{|c|}{1928 Taper } \\
\hline $\begin{array}{l}\text { Section height } \\
\text { in per cent of } \\
\text { height above } \\
\text { breast height }\end{array}$ & $\begin{array}{l}\text { Diameter } \\
\text { inside bark, } \\
\text { in inches }\end{array}$ & $\begin{array}{l}\text { Diameter inside } \\
\text { bark, in per cent } \\
\text { of diameter } \\
\text { breast high } \\
\text { inside bark }\end{array}$ & $\begin{array}{l}\text { Section height, } \\
\text { in per cent of } \\
\text { height above } \\
\text { breast height }\end{array}$ & $\begin{array}{l}\text { Diameter } \\
\text { inside bark, } \\
\text { in inches }\end{array}$ & $\begin{array}{l}\text { Diameter inside } \\
\text { bark, in per cent } \\
\text { of diameter } \\
\text { breast high } \\
\text { inside bark }\end{array}$ \\
\hline 0 & 13.2 & 100 & 0 & 19.7 & 100 \\
\hline 10 & 11.5 & 87 & 10 & 18.4 & 93 \\
\hline 20 & 10.8 & 82 & 20 & 17.4 & 88 \\
\hline 30 & 10.6 & 80 & 30 & 16.0 & 81 \\
\hline 40 & 10.2 & 77 & 40 & 14.3 & 72 \\
\hline 50 & 8.5 & 64 & 50 & 12.6 & 64 \\
\hline 60 & 6.9 & 52 & 60 & 10.6 & 54 \\
\hline 70 & 5.6 & 42 & 70 & 8.2 & 42 \\
\hline 80 & 4.1 & 31 & 80 & 5.7 & 29 \\
\hline 90 & 2.7 & 20 & 90 & 3.6 & 18 \\
\hline 100 & 0.0 & 0 & 100 & 0.0 & 0 \\
\hline
\end{tabular}

* In 1909 the diameter breast high inside bark was 13.2 inches, and the height above breast height 83 feet. In 1928 the diameter breast high inside bark was 19.7 inches, and the height above breast height 107.5 feet.

With the data put up in this form the evident and positive relations which are associated with tree size only, are eliminated because upper diameters are in units which in themselves are independent of size; for instance, the diameter in inches halfway up a 10-inch tree is obviously less than the diameter halfway up a 60 -inch tree, even should the percentage diameters be the same. It follows that identical percentage diameters at corresponding percentile heights mean identical form—a fact which may be completely hidden if absolute units are used. 
Site quality is, broadly at least, common to all the data, while such variables as age, crown size, and vigor, which make up the basic factors of tree classification, are treated together, though only in an indirect way, through the detection of form differences of the several tree classes.

The 1928 Taper of the Trees from the Virgin Stand.-Attention was first focused on the 1928 taper of the trees from the virgin stand; indeed, the 1909 tapers of both the virgin and cut-over stands might have been combined with it and the three sets analyzed as one, there being no reason to suspect that in their average values they should be at all unlike. Still the latter two sets cannot be considered as having. been as accurately measured in the field as the former. This follows from the usual method of taking stem analyses.

At each cross section of every tree, a penciled line was drawn from pith to cambium along the average radius. By definition this is average radius to the cambium of 1928 , though the radius along this line to the 1909 annual ring may or may not have been average for any one section in 1909. Hence while the means of the 1909 radii become reliable with sufficient number of trees, greater dispersion is to be expected on account of the discrepancies inherent in the method of taking individual 1909 measurements.

The attempt to correlate percentage diameter inside bark with percentile height, diameter breast high inside bark, and total height above breast height, as a curvilinear relation in four variables in the usual way, was unsuccessful because of the failure to translate the functional form of the regression equation to an alignment chart of the additive type, i.e., a chart with parallel axes. Since the trees must have zero diameter at their tips, and 100 per cent diameter at breast height, it follows that the percentile height axis and the percentage diameter axis must meet at base and tip, necessitating a curved axis for one or both of these variables in order to meet the other at the two necessary points. If the tapers were independent of either diameter inside bark at breast height or total height above breast height, a chart with one curved axis might have been constructed without difficulty by intersection.

It was finally decided to study the relations at each given percentile height separately. Then percentage diameter inside bark was correlated with diameter breast high inside bark in inches, and total height above breast height in feet, at each tenth of height above breast height. Table 7 sets forth the results. 


\section{TABLE 7}

Correlation and Regression Comfficients of Diameter. Inside Bark for. Known Diameter Breast High Inside Bark and Total Height Above Breast Height, at Given Percentage Hetghts Above Breast Height

\begin{tabular}{c|c|c|c}
\hline \hline \multirow{2}{*}{$\begin{array}{c}\text { Per cent } \\
\text { height }\end{array}$} & $\begin{array}{c}\text { Correlation } \\
\text { coefficient, } \\
r_{1.23}\end{array}$ & \multicolumn{2}{|c}{ Regression coefficients } \\
\cline { 3 - 4 } & 0.224 & $b_{12.3}$ & $b_{13.2}$ \\
\hline 10 & .447 & +0.021 & +0.006 \\
20 & .602 & +.002 & +.034 \\
30 & .601 & +.003 & +.052 \\
40 & .641 & +.001 & +.059 \\
50 & .538 & +.077 & +.058 \\
60 & .495 & +.032 & +.034 \\
70 & .245 & +.074 & +.002 \\
80 & 0.123 & +0.035 & -0.020 \\
90 & & & +.041 \\
\hline
\end{tabular}

* Subscript 1 refers to per cent diameter inside bark; subscript 2 refers to diameter breast high inside bark in inches; subscript 3 refers to total height above breast height in feet.

An alignment chart was next constructed for each regression equation and deviations of the percentage diameters were plotted over the net regression lines for diameter breast high with average height above breast height, and for height with average diameter. The calculated straight lines indicated the best fit to the data, but as they were not harmonized with percentage height the following values were plottted over percentile height and adjusted by free-hand curves:

(1) The means of the percentage diameters (fig. $5 A$ ).

$(2)$ The slope of the net regression line $\left(b_{12.3}\right)$ of percentage diameter on diameter breast high at the several percentile heights (fig. $5 B$ ).

(3) The slope of the net regression line $\left(b_{13 \cdot 2}\right)$ of percentage diameter on total height at the several percentile heights (fig. $5 C$ ).

Figures 6 and 7 portray graphically the final assemblage of the percentage diameter with the adjusted regression lines, figure 6 showing the fit to the data for diameter with average height, and figure 7 for height with average diameter.

As a check on the work thus far the corrections for diameter breast high inside bark and total height were added to the curved diameters of figure $5 \mathrm{~A}$. Comparison of actual with calculated percentage diameters revealed that the standard error of estimate increases from base to tip as brought out in table 8 . 

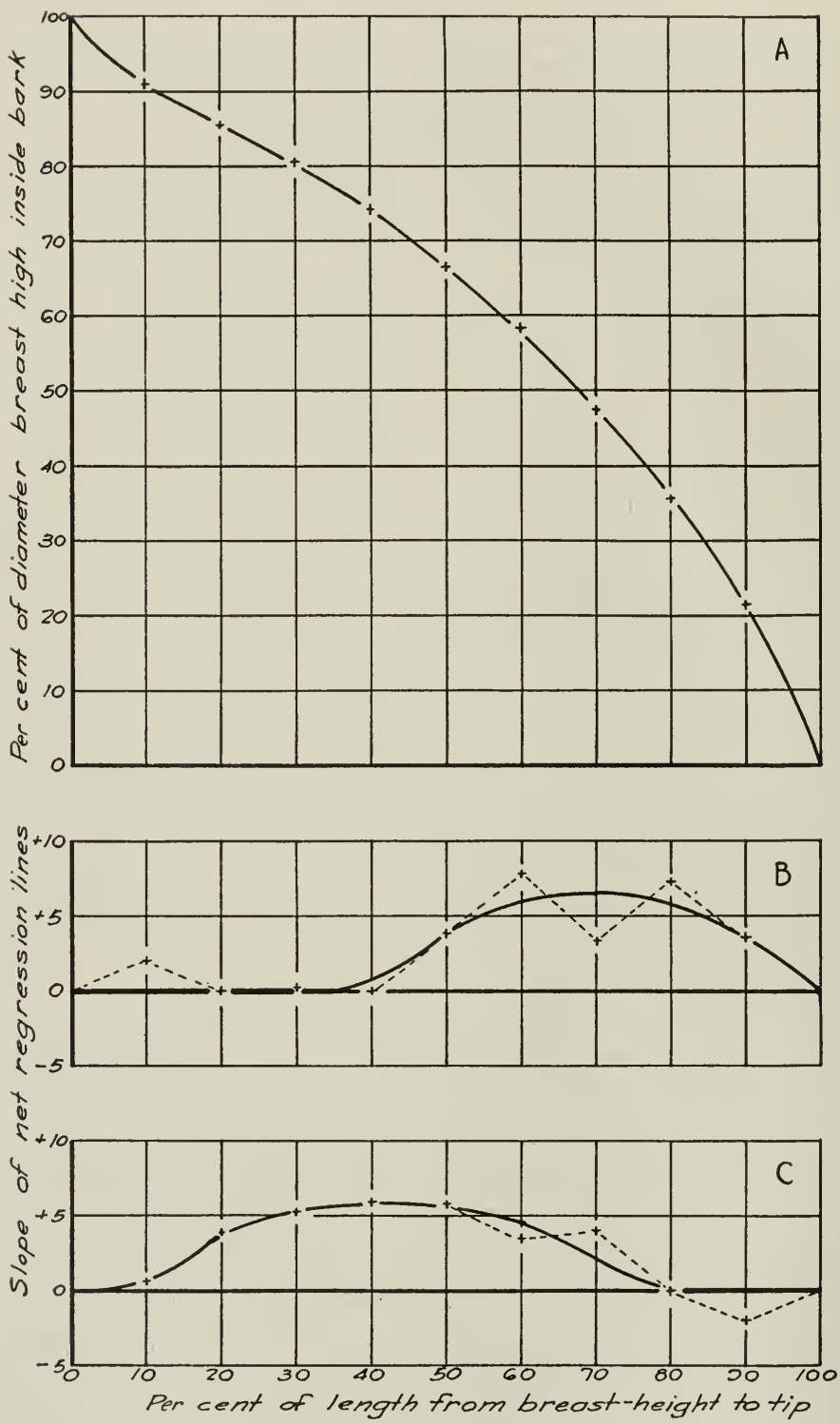

Fig. 5.-Curves that harmonize the relation of taper to tree size. $A$, The average taper of all trees. $B$, The net regression slopes of percentage diameter on diameter breast high harmonized with percentile height. $C$, The net regression slopes of percentage diameter on height harmonized with percentile height. 
A further check was afforded in the calculation of the board-foot volumes from the estimated taper curves of the same number of trees by diameter breast high outside bark and total height classes as were used in the volume table check. This operation was carried out after bark thickness at breast height was correlated with diameter breast high outside bark and total height. ${ }^{7}$ A taper curve was drawn for each

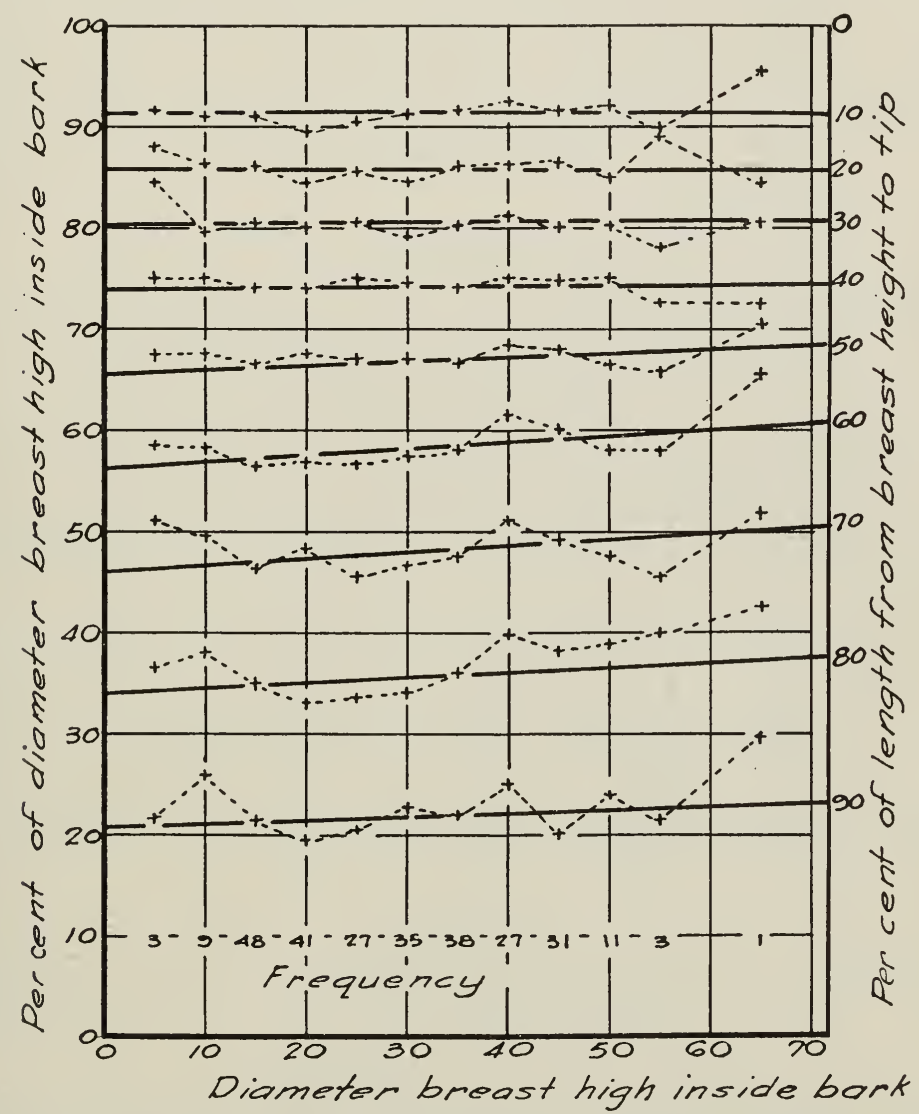

Fig. 6.-Comparison of actual tapers with the curved, by diameter-breast-high classes for average height.

5-inch diameter-breast-high class and 10 -foot height class in which actual trees were found, and the volumes of each of these tapers weighted according to the number of trees in the class. The aggregate volume of the 285 trees is 854,600 board feet and the aggregate volume from the estimated taper curves 854,560 board feet, rendering a very satisfactory check.

7 The analysis of bark-thickness relations is discussed on p. 24 . 


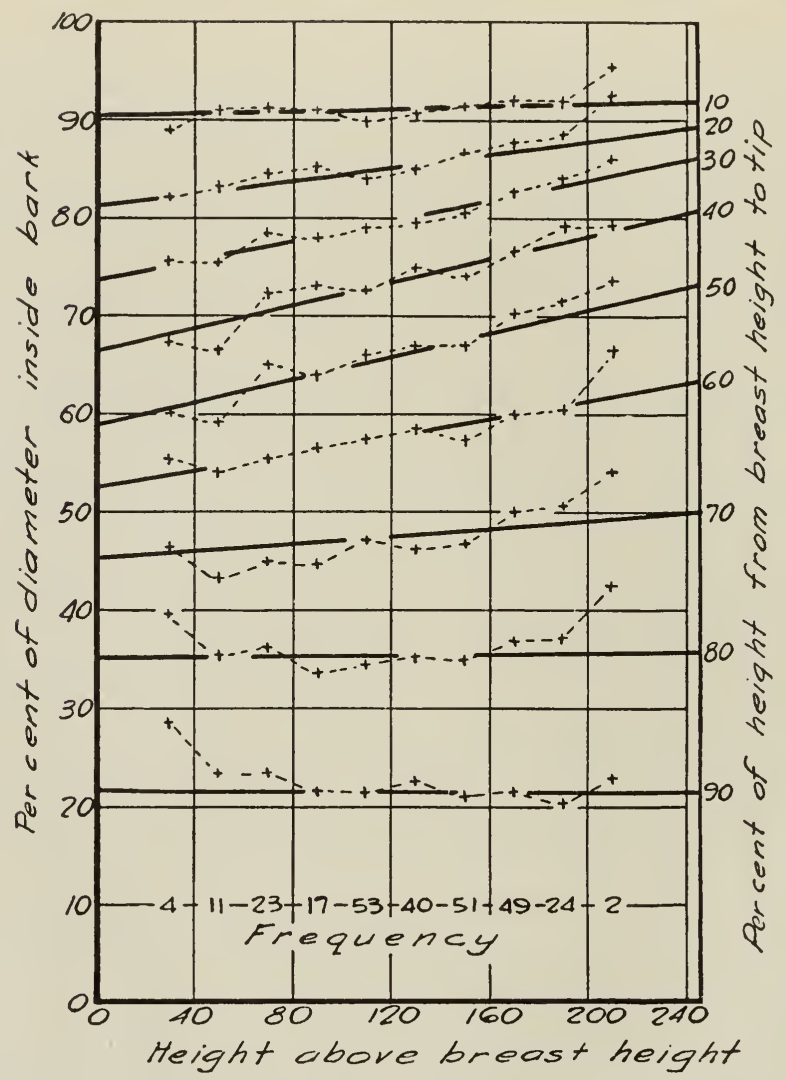

Fig. 7.-Comparison of actual tapers with the curved, by height classes for average diameter breast high.

TABLE 8

Standard Errors at Given Percentile Heights in the Estimate of Diameter Inside Bark, in Per Cent*

\begin{tabular}{|c|c|}
\hline Per cent height & $\begin{array}{c}\text { Standard error } \\
\text { of estimate, } \\
\text { per cent }\end{array}$ \\
\hline 10. & 4.98 \\
\hline $20 \ldots$ & 4.56 \\
\hline $30 \ldots$ & 5.05 \\
\hline $40 \ldots \ldots$ & 5.35 \\
\hline $50 \ldots \ldots$ & 5.25 \\
\hline $60 \ldots$ & 6.31 \\
\hline $70 \ldots \ldots$ & 7.28 \\
\hline $80 \ldots \ldots$ & 8.52 \\
\hline $90 \ldots \ldots \ldots \ldots$ & 8.12 \\
\hline A verage.............. & 6.31 \\
\hline
\end{tabular}

* From known diameter at breast height inside bark, total height above breast height, and percentile height to point of estimate. 
Comparison of the Tree Tapers from the Virgin and Cut-over Stands in 1909 and 1928.-The percentile diameters of the trees from the virgin-stand 1909 taper and from the cut-over-stand 1909 and 1928 tapers were then checked individually with the calculated percentage diameters of the 1928 virgin stand for diameter breast high and height. At once differences were encountered which may or may not be chance fluctuations. But as the three sets all ran higher than the diameters to which they were compared, the base was shifted from the taper of the 1928 virgin stand to the average of the four sets, as is brought out in table 9 , in which the comparison is made.

\section{TABLE 9}

Comparison of Average Differences in Percentage Diameteris Inside Bark at EACH TeNth of Length From Breast Height to TIP of the

Trees From the Virain and CuT-over Stands, 1909 AND 1928 TAPERS

\begin{tabular}{|c|c|c|c|c|c|}
\hline \multirow{3}{*}{$\begin{array}{l}\text { Per cent height above } \\
\text { breast height }\end{array}$} & \multirow{3}{*}{$\begin{array}{l}\text { A verage } \\
\text { per cent } \\
\text { diameter } \\
\text { inside bark }\end{array}$} & \multicolumn{4}{|c|}{$\begin{array}{c}\text { Deviation from average percentage diameter inside bark, } \\
\text { in per cent }\end{array}$} \\
\hline & & \multicolumn{2}{|c|}{ Virgin stand } & \multicolumn{2}{|c|}{ Cut-over stand } \\
\hline & & 1909 & 1928 & 1909 & 1928 \\
\hline $10 .$. & 91.7 & +0.33 & -0.44 & -0.34 & -0.05 \\
\hline 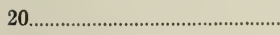 & 86.4 & +0.24 & -0.63 & +0.87 & +0.05 \\
\hline $30 \ldots \ldots$ & 81.8 & +0.28 & -1.00 & +0.85 & +0.92 \\
\hline$x^{2}$ & 75.4 & +0.13 & -1.22 & +1.55 & +1.14 \\
\hline 50 & 68.1 & -0.02 & -1.27 & +1.17 & +2.04 \\
\hline 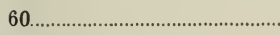 & 59.5 & -0.11 & -1.07 & +1.14 & +1.65 \\
\hline (1) & 49.2 & +0.09 & -1.33 & +1.25 & +1.80 \\
\hline 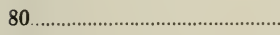 & 36.8 & +0.22 & -1.39 & +1.22 & +1.60 \\
\hline $90 \ldots$ & 22.6 & -0.01 & -1.04 & +0.90 & +1.67 \\
\hline \multirow{3}{*}{\multicolumn{2}{|c|}{$\begin{array}{l}\text { Number of trees } \\
\text { Standard error of mean }\end{array}$}} & +0.13 & -1.04 & +1.03 & +1.20 \\
\hline & & 273 & 273 & 112 & 112 \\
\hline & & \pm 0.38 & \pm 0.38 & \pm 0.60 & \pm 0.60 \\
\hline
\end{tabular}

* The standard error of estimate on which these standard errors of the means are based is 6.31 per cent, taken from table 8. This, the standard error of estimate of the 1928 taper of the trees from the virgin stand is considered the best estimate of the dispersion because of the greater accuracy possible when measuring individual tree tapers in the field.

One might suppose that the 1928 tapers of the cut-over trees differ from the others because of the opening up of the stand at the time of the 1910 logging. But the three remaining sets, which ought to be identical except for chance variation, reflecting as they do the environment of the virgin forest, differ from one another by as much as the 1928 cut-over tapers differ from them.

Factors of stand or site not readily observed on the ground may account for the higher percentage diameters of the 1909 cut-over trees 
when compared to the 1909 virgin trees; nothing in the data has been detected which serves to explain the differences. But judging by the mean difference with its standard error of any one set from the average of the four, there is no evidence pointing to the abnormality of any one set. The taper tables presented (table 4) are therefore based upon the average of the four sets of data.

The Taper by Tree Class.-The deviations of percentage diameters of the virgin and cut-over trees, 1909 and 1928 tapers were segregated according to tree class and plotted over percentage height, the curves of figure 8 resulting.

\section{BARK THICKNESS AT BREAST HEIGHT}

An investigation of bark thickness at breast height is necessary for the application of taper tables which are based upon inside bark diameters at breast height; for, on account of the time required to measure inside bark diameters of standing trees, the bark is almost never measured in practical woods work.

The actual bark figure used for each tree is the difference between diameter breast high outside and inside bark, that is, double bark thickness. This was correlated with diameter outside bark and with total height. Figure 9 shows the net regression curves for the virgin stand. On comparing the bark of the cut-over trees with these curves by means of the alignment chart, it was found that while the nature of the relation is the same with increasing diameter and height, the mean is about 8 per cent less. Therefore, in the construction of the taper tables, diameter breast high inside bark is based upon the outside bark diameters of the trees from the virgin stand only. Furthermore, as the thickness of bark is but poorly correlated with height, the latter may be dropped as a variable and inside bark diameters safely based upon diameter outside bark only (fig. 10), thus simplifying the work.

\section{THE TAPER TABLES}

From the foregoing analyses, complete taper curves for the species on Site Quality I have been built up. If diameter breast high outside bark is given, diameter breast high inside bark can be obtained from figure 10. To the average percentage diameters of table 9 , corrections for the size of the tree according to figures 6 and 7 are added. The tapers of table 4 were constructed in this way. If tables for separate crown classes should be required, values from table 5 , which are taken from figure 8 , are to be added. 

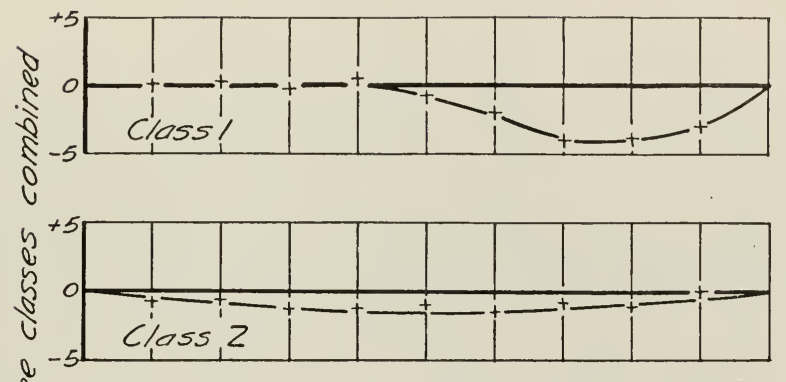

है
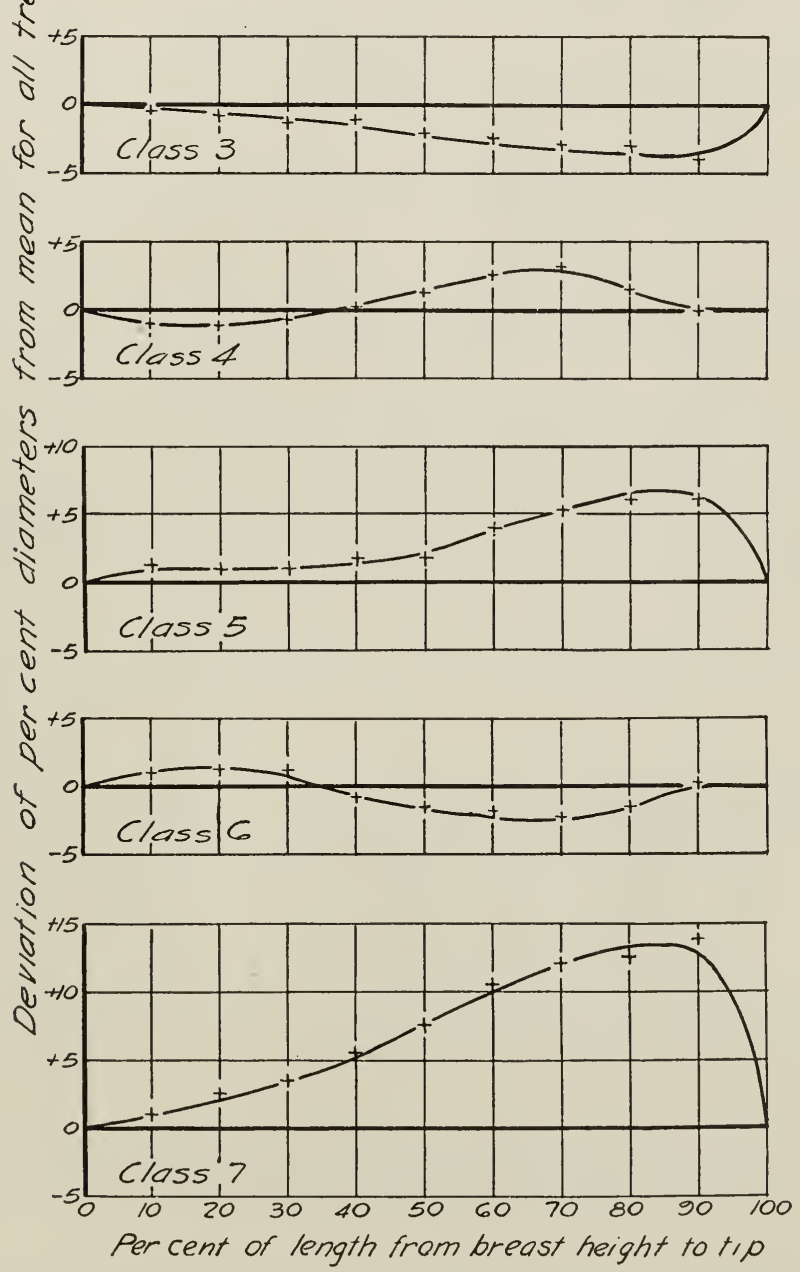

Fig. 8.-Deviation of the taper of each tree class from the average taper of all classes combined. 

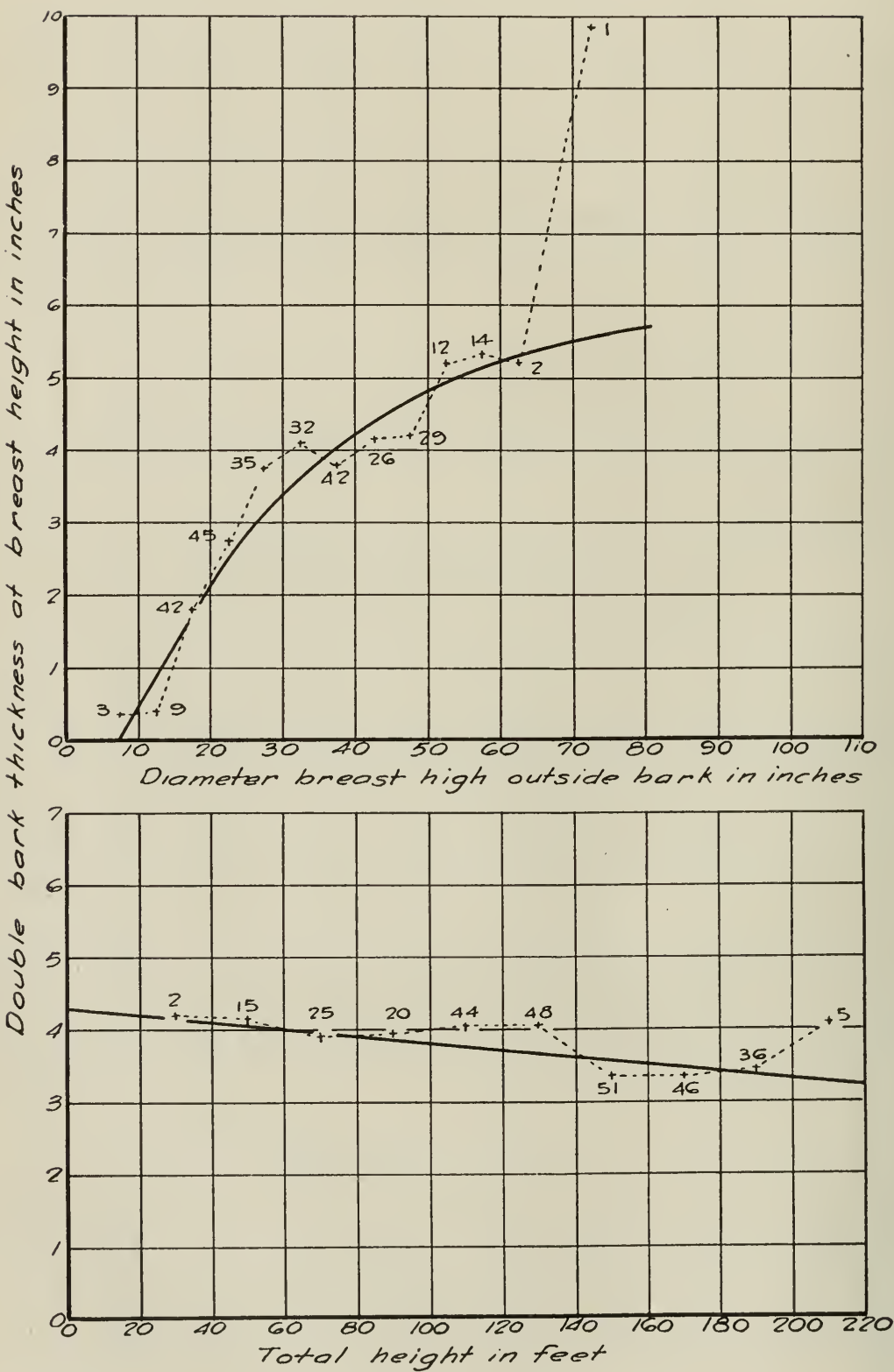

Fig. 9.-Relation of double bark thickness to diameter breast high for average height and to height for average diameter breast high, for virgin stand. 


\section{DIAMETER GROWTH}

One of the objects of the investigation is to determine to what extent the growth of individual western yellow pine trees may be stimulated by affording them more room in which to grow after partial cutting. This has been accomplished by comparing inside bark diameter growth between 1910 and 1928 of the trees from the cut-over stand with those from the virgin stand at 10 equidistant points along the stem, after

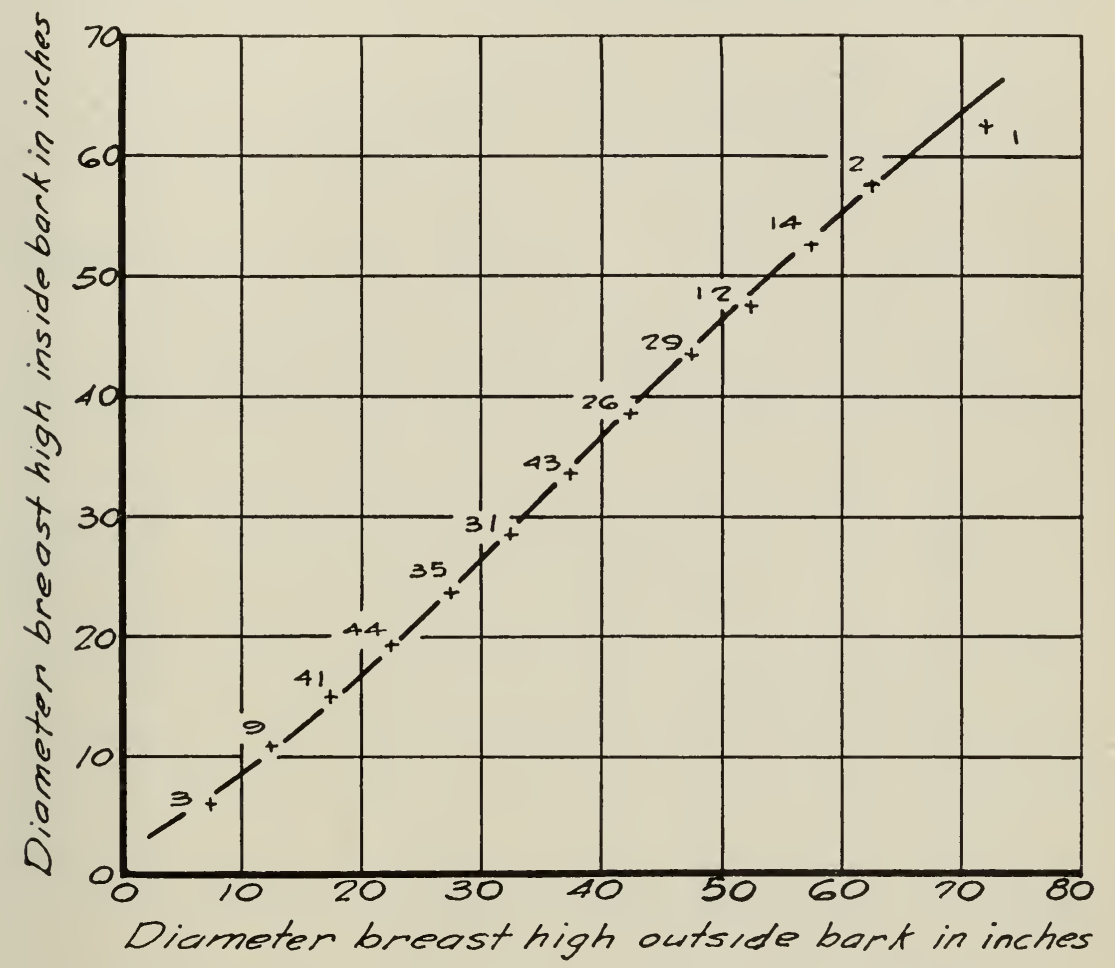

Fig. 10.-Relation between diameter breast high inside bark and diameter breast high outside bark, for virgin stand.

making corrections for diameter breast high, total height, height growth from 1910 to 1928, and the point along the stem of measuring diameter growth.

Table 10, which gives average values of the trees from the virgin and cut-over stands by tree class, brings out the following, apparently important, facts :

1. The average 1909 diameter of the trees from the virgin stand is higher than the same diameter of the trees from the cut-over stand. This is natural, as the best specimens were no doubt removed from the 
cut-over stand in the 1910 logging, and the trees left had not yet caught up when the 1928 logging occurred.

2. The periodic diameter growth at breast height between 1910 and 1928 is greater in the trees from the cut-over stand, except in classes 2 and 6 , and these are poorly represented. In like manner this is to be expected after the opening up of the cut-over stand in 1910, and indicates that the diameters at breast height of the latter stand had tended to catch up with those of the former.

TABLE 10

Comparison of Average Size in 1909 and Averiage Diameter and Height Growth FROM 1910 TO 1928 OF THE BASIC TREES

\begin{tabular}{|c|c|c|c|c|c|c|c|c|c|c|}
\hline \multirow{2}{*}{$\begin{array}{l}\text { Tree } \\
\text { class }\end{array}$} & \multicolumn{2}{|c|}{$\underset{\text { trees }}{\text { Number of }}$} & \multicolumn{2}{|c|}{$\begin{array}{l}\text { A verage diameter } \\
\text { breast high } \\
\text { inside bark } \\
\text { in } 1909\end{array}$} & \multicolumn{2}{|c|}{$\begin{array}{c}\text { Average diameter } \\
\text { growth at breast } \\
\text { height inside } \\
\text { bark, 1910-1928 }\end{array}$} & \multicolumn{2}{|c|}{$\begin{array}{l}\text { Average total } \\
\text { height in } 1909\end{array}$} & \multicolumn{2}{|c|}{$\begin{array}{c}\text { Average height } \\
\text { growth, 1910-1928 }\end{array}$} \\
\hline & $\begin{array}{l}\text { Virgin } \\
\text { stand }\end{array}$ & $\begin{array}{l}\text { Cut-over } \\
\text { stand }\end{array}$ & $\begin{array}{l}\text { Virgin } \\
\text { stand }\end{array}$ & $\begin{array}{c}\text { Cut-over } \\
\text { stand }\end{array}$ & $\begin{array}{l}\text { Virgin } \\
\text { stand }\end{array}$ & $\begin{array}{c}\text { Cut-over } \\
\text { stand }\end{array}$ & $\begin{array}{l}\text { Virgin } \\
\text { stand }\end{array}$ & $\begin{array}{l}\text { Cut-over } \\
\text { stand }\end{array}$ & $\begin{array}{l}\text { Virgin } \\
\text { stand }\end{array}$ & $\begin{array}{l}\text { Cut-over } \\
\text { stand }\end{array}$ \\
\hline 1 & 40 & 20 & $\begin{array}{c}\text { inches } \\
20.7\end{array}$ & $\begin{array}{c}\text { inches } \\
19.2\end{array}$ & $\begin{array}{c}\text { inches } \\
3.32\end{array}$ & $\begin{array}{c}\text { inches } \\
3.65\end{array}$ & $\begin{array}{l}\text { feet } \\
110\end{array}$ & $\begin{array}{l}\text { feet } \\
114\end{array}$ & $\begin{array}{l}\text { feet } \\
18.0\end{array}$ & $\begin{array}{l}\text { feet } \\
7.5\end{array}$ \\
\hline 2 & 43 & 3 & 14.7 & 13.6 & 2.42 & 1.47 & 94 & 98 & 17.7 & 5.8 \\
\hline 3 & 74 & 25 & 35.8 & 34.7 & 1.80 & 2.47 & 163 & 163 & 7.9 & 3.7 \\
\hline 4 & 49 & 25 & 30.1 & 25.8 & 1.72 & 2.24 & 140 & 139 & 5.5 & 4.5 \\
\hline 5 & 40 & 14 & 41.8 & 40.8 & 1.38 & 1.96 & 165 & 160 & 2.3 & 1.2 \\
\hline 6 & 30 & 8 & 12.0 & 10.2 & 2.11 & 2.06 & 62 & 52 & 8.4 & 8.0 \\
\hline 7 & 17 & 17 & 15.7 & 14.7 & 1.34 & 1.85 & 60 & 64 & 1.3 & 0.5 \\
\hline
\end{tabular}

3. There are significant differences in total height between the two sets of data in certain classes, though not in the same direction from class to class; this is the result, probably, of selection by quality rather than by mere size, at the time of the 1910 logging in the cut-over stand.

4. All tree classes in the cut-over stand have made less height growth after the 1910 logging. Acceleration of diameter growth has been accompanied by retardation of height growth.

If complete stem analyses of the trees from the cut-over stand had been taken at the time of the 1928 logging, the analysis of the progress of growth during a preceding period of, say 50 to 75 years, would give fairly exact information regarding changes in growth rate and form, by comparing the 18-year growth from 1910 to 1928 with a number of preceding 18-year periods on the same trees. Unfortunately, complete stem analyses were not taken because of the doubt that there would be sufficient time in the interval between the bucking and the yarding of the trees.

On the other hand, the assignment of individuals to proper tree class of 50 or 75 years ago is subject to grave error, as vigor, color of foliage, and relation to neighbors at that time are matters largely of 
guess; and changes in growth are dependent not only upon advancing age, but also upon a number of factors which are expressed in their summation by assignment of individuals to tree class. Altogether, then, it seems that what may be lost by comparing the growth after release of one set of trees with growth before release of a separate set, is more than compensated for by the relative assurance that trees of the same class are compared together.

From the original tree tapers on form 558a the data were set up by reading off the 1909 diameters inside bark in inches at breast height and at each tenth of the 1909 height above breast height, then reading the 1928 diameters inside bark at the same points along the stem as the earlier diameters; the difference leaves diameter growth at the given point. Table 11 shows the form in which data of each tree were arranged.

TABLE 11

Sample Arrangement of Tree Data for Growth Study

(Tree of class 1 from virgin stand; diameter breast.

high outside bark, 1909, 22.2 inches)

\begin{tabular}{|c|c|c|c|c|}
\hline \multicolumn{4}{|c|}{ Diameter data } & \multirow{3}{*}{ Height data } \\
\hline \multirow{2}{*}{$\begin{array}{l}\text { Height above } \\
\text { breast height, } \\
1909\end{array}$} & \multicolumn{2}{|c|}{$\begin{array}{l}\text { Diameter inside bark } \\
\text { at given height }\end{array}$} & \multirow{2}{*}{$\begin{array}{l}\text { Diameter } \\
\text { growth, } \\
1910-1928\end{array}$} & \\
\hline & 1909 & 1928 & & \\
\hline percent & inches & inches & inches & feet \\
\hline 0 & 17.4 & 19.8 & 2.4 & Total height, $1909 \ldots \ldots$ \\
\hline 10 & 16.7 & 19.0 & 2.3 & Total height, $1928 \ldots \ldots \ldots \ldots \ldots \ldots . . .125$ \\
\hline 20 & 16.0 & 18.2 & 2.2 & Height growth....................... 16 \\
\hline 30 & 15.3 & 17.5 & 2.2 & \\
\hline 40 & 14.3 & 16.7 & 2.4 & \\
\hline 50 & 13.2 & 15.5 & 2.3 & \\
\hline 60 & 11.4 & 14.1 & 2.7 & \\
\hline 70 & 9.2 & 11.9 & 2.7 & \\
\hline 80 & 7.3 & 9.3 & 2.0 & \\
\hline 90 & 4.4 & 7.0 & 2.6 & \\
\hline 100 & 0.0 & 4.5 & 4.5 & \\
\hline
\end{tabular}

The 1928 diameter measurements at the tip of the 1909 tapers were not used in this part of the study because they could not be read with any degree of accuracy since the diameter scale of form 558a, set as it is according to the square of diameter, is fairly easy to read for the larger values back from the tip, but difficult for the small diameters near the tip.

Combining the trees from the virgin and cut-over stands in the first estimate, the periodic diameter growth was correlated with (1) 1909 diameter at breast height inside bark, (2) 1909 total height of tree, (3) height growth from 1910 to 1928, and with (4) the 1909 percentile heights. After setting up the linear relation in alignment chart form, 

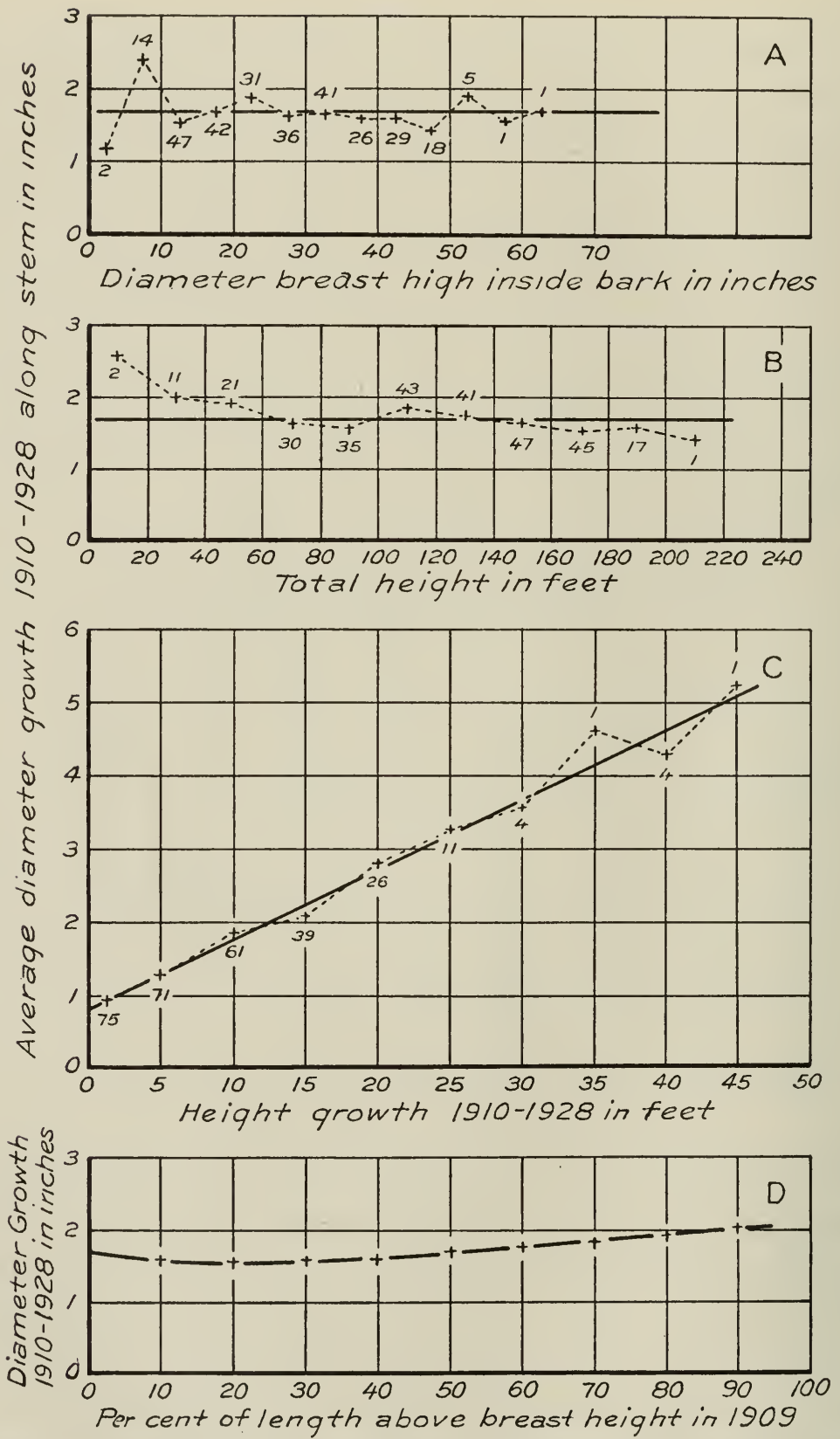

Fig. 11.-Diameter growth along the stem as associated with $A$, diameter breast high ; $B$, height ; $C$, height growth; and $D$, percentile height. . Trees from the virgin stand. 

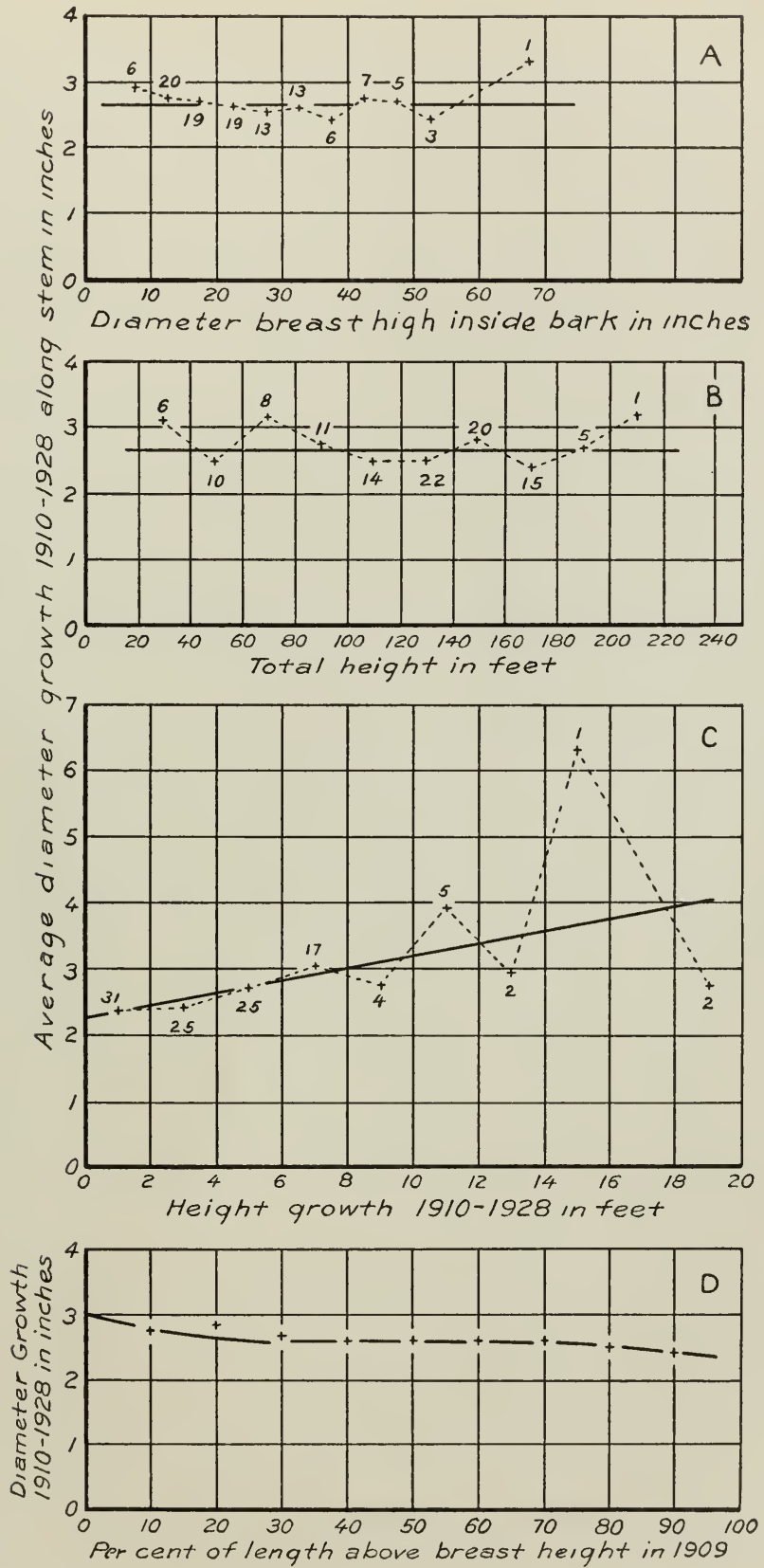

Fig. 12.-Diameter growth along the stem as associated with $A$, diameter breast high; $B$, height; $C$, height growth; and $D$, percentile height. Trees from the cut-over stand. 
succeeding estimates, three of which were required, were made separately for the two sets of data. In figures 11 and 12 the deviations of the actual periodic growth figures are plotted over the net regression lines for the virgin and eut-over stands respectively.

The outstanding features common to both sets of data are the following :

1. Average diameter growth along the stem and size of tree-that is, diameter of trunk and total height-are practically independent of one another (figs. $11 A$ and $B$, and $12 A$ and $B$ ).

2. Average diameter growth along the stem and height growth of tree are interdependent. An analogy may explain this: Given two similar isosceles triangles so placed that the midpoints of their bases are common. Then the basal measurement of one over that of the other is increased by increasing its altitude; and measurements parallel to the base are increased by the same amount. Conversely, by increasing basal measurement of one over that of the other, its altitude is likewise increased.

On the other hand, tree form apparently tends to change after release, as is brought out upon comparing figures $11 D$ and $12 D$, though the time interval has not been long enough to affect significantly the relative tapers in 1928. In general, the periodic diameter growth of the virgin stand decreases slightly from breast height to a point about one-quarter of the way up and thereafter increases; while the diameter growth of the cut-over trees decreases slightly from breast height to tip.

Comparison of diameter growth of the virgin and cut-over stands by tree class is made in figure 2. The plotted points are the average deviations of the actual diameter growth from the estimated, for given percentage heights and height growth of the trees, added to the estimated diameter growth based upon average height growth of each tree class of the cut-over stand.

\section{CONCLUSION}

The results of the comparison of the trees from the virgin stand with those from the cut-over stand are not sufficiently definite to warrant an assertion that partial logging in western yellow pine is followed by increase of volume growth rate in the trees of the residual stand. From the diameter, height, and growth data of table 10, volume growth during the period 1910-1928 is about the same in the two stands. The greater diameter growth of the trees from the cut-over stand has been offset by the greater height growth of the trees from the virgin stand. 